\title{
Review of the Emerging Evidence Demonstrating the Efficacy of Ivermectin in the Prophylaxis and Treatment of COVID-19
}

Pierre Kory, $\mathrm{MD}^{1 *}$, G. Umberto Meduri, $\mathrm{MD}^{2} \dagger$, Jose Iglesias, $\mathrm{DO}^{3}$, Joseph Varon, $\mathrm{MD}^{4}$, Keith Berkowitz, MD ${ }^{5}$, Howard Kornfeld, $\mathrm{MD}^{6}$, Eivind Vinjevoll, $\mathrm{MD}^{7}$, Scott Mitchell, MBChB ${ }^{8}$, Fred Wagshul, MD ${ }^{9}$, Paul E. Marik, $\mathrm{MD}^{10}$

1 Front-Line Covid-19 Critical Care Alliance.

2 Memphis VA Medical Center - Univ. of Tennessee Health Science Center, Memphis, TN.

3 Hackensack School of Medicine, Seton Hall, NJ.

4 University of Texas Health Science Center, Houston, TX.

5 Center for Balanced Health, New York

6 Recovery Without Walls

Volda Hospital, Volda, Norway

Princess Elizabeth Hospital, Guernsey, UK

9 Lung Center of America, Dayton, Ohio

${ }^{10}$ Eastern Virginia Medical School

* Correspondence:

Corresponding Author: Pierre Kory, MD, MPA pkory@flccc.net

1 These authors have contributed equally to this work

$\dagger$ Dr. Meduri's contribution is the result of work supported with the resources and use of facilities at the Memphis VA Medical Center. The contents of this commentary do not represent the views of the U.S. Department of Veterans Affairs or the United States Government

\section{Keywords}

Ivermectin, COVID-19, infectious disease, pulmonary infection, respiratory failure

\section{Manuscript Length}

Number of words: 8185 ; lines: 790; tables: 4; figures: 7.

\begin{abstract}
In March 2020, the Front Line COVID-19 Critical Care Alliance (FLCCC) was created and led by Professor Paul E. Marik to continuously review the rapidly emerging basic science, translational, and clinical data to develop a treatment protocol for COVID-19. The FLCCC then recently discovered that ivermectin, an anti-parasitic medicine, has highly potent anti-viral and anti-inflammatory properties against COVID-19. They then identified repeated, consistent, large magnitude improvements in clinical outcomes in multiple, large, randomized and observational controlled trials in both prophylaxis and treatment of COVID-19. Further, data showing impacts on population wide health outcomes have resulted from multiple, large "natural experiments" that occurred when various
\end{abstract}




\section{Efficacy of Ivermectin in COVID-19}

city mayors and regional health ministries within South American countries initiated "ivermectin distribution" campaigns to their citizen populations in the hopes the drug would prove effective. The tight, reproducible, temporally associated decreases in case counts and case fatality rates in each of those regions compared to nearby regions without such campaigns, suggest that ivermectin may prove to be a global solution to the pandemic. This was further evidenced by the recent incorporation of ivermectin as a prophylaxis and treatment agent for COVID-19 in the national treatment guidelines of Belize, Macedonia, and the state of Uttar Pradesh in Northern India, populated by 210 million people. To our knowledge, the current review is the earliest to compile sufficient clinical data to demonstrate the strong signal of therapeutic efficacy as it is based on numerous clinical trials in multiple disease phases. One limitation is that half the controlled trials have been published in peerreviewed publications, with the remainder taken from manuscripts uploaded to medicine pre-print servers. Although it is now standard practice for trials data from pre-print servers to immediately influence therapeutic practices during the pandemic, given the controversial therapeutics adopted as a result of this practice, the FLCCC argues that it is imperative that our major national and international health care agencies devote the necessary resources to more quickly validate these studies and confirm the major, positive epidemiological impacts that have been recorded when ivermectin is widely distributed among populations with a high incidence of COVID-19 infections.

\section{Introduction}

In March 2020, an expert panel called the Front Line COVID-19 Critical Care Alliance (FLCCC) was created and led by Professor Paul E. Marik. ${ }^{1}$ The group of expert critical care physicians and thought leaders immediately began continuously reviewing the rapidly emerging basic science, translational, and clinical data in COVID-19 which then led to the early creation of a treatment protocol for hospitalized patients based on the core therapeutic interventions of methylprednisolone, ascorbic acid, thiamine and heparin (MATH+), with the "+" referring to multiple, optional adjunctive treatments. The MATH+ protocol was based on the collective expertise of the group in both the research and treatment of multiple other severe infections causing lung injury.

Two manuscripts reviewing different aspects of both the scientific rationale and evolving published clinical evidence in support of the MATH+ protocol were published in major medical journals at two different time points in the pandemic (Kory et al., 2020; Marik et al., 2020). The most recent paper reported a $6.1 \%$ hospital mortality rate in COVID-19 patients measured in the two U.S hospitals that systematically adopted the MATH+ protocol (Kory et al., 2020). This was a markedly decreased mortality rate compared to the $23.0 \%$ hospital mortality rate calculated from a review of 45 studies including over 230,000 patients (unpublished data; available on request).

Although the adoption of MATH+ has been considerable, it largely occurred only after the treatment efficacy of the majority of the protocol components (corticosteroids, ascorbic acid, heparin, statins, Vitamin D, melatonin) were either validated in subsequent randomized controlled trials or more strongly supported with large observational data sets in COVID-19 (Entrenas Castillo et al., 2020; Horby et al., 2020; Jehi et al., 2020;Nadkarni et al., 2020;Rodriguez-Nava et al., 2020;Zhang et al., 2020a;Zhang et al., 2020b). Despite the plethora of supportive evidence, the MATH+ protocol for hospitalized patients has not yet become widespread. Further, the world is in a worsening crisis with the potential of again overwhelming hospitals and ICU's. As of December $31^{\text {st }}, 2020$, the number of deaths attributed to COVID-19 in the United States reached 351,695 with over 7.9 million active

https://www.flccc.net 


\section{Efficacy of Ivermectin in COVID-19}

cases, the highest number to date. ${ }^{2}$ Multiple European countries have now begun to impose new rounds of restrictions and lockdowns. ${ }^{3}$

Further compounding these alarming developments was a wave of recently published results from therapeutic trials done on medicines thought effective for COVID-19 which found a lack of impact on mortality with use of remdesivir, hydroxychloroquine, lopinavir/ritonavir, interferon, convalescent plasma, tocilizumab, and mono-clonal antibody therapy (Agarwal et al., 2020;Consortium, 2020; Hermine et al., 2020; Salvarani et al., 2020). ${ }^{4}$ One year into the pandemic, the only therapy considered "proven" as a life-saving treatment in COVID-19 is the use of corticosteroids in patients with moderate to severe illness (Horby et al., 2020). Similarly, most concerning is the fact that little has proven effective to prevent disease progression to prevent hospitalization.

Fortunately, it now appears that ivermectin, a widely used anti-parasitic medicine with known anti-viral and anti-inflammatory properties is proving a highly potent and multi-phase effective treatment against COVID-19. Although growing numbers of the studies supporting this conclusion have passed through peer review, approximately half of the remaining trials data are from manuscripts uploaded to medical pre-print servers, a now standard practice for both rapid dissemination and adoption of new therapeutics throughout the pandemic. The FLCCC expert panel, in their prolonged and continued commitment to reviewing the emerging medical evidence base, and considering the impact of the recent surge, has now reached a consensus in recommending that ivermectin for both prophylaxis and treatment of COVID-19 should be systematically and globally adopted.

The FLCCC recommendation is based on the following set of conclusions derived from the existing data, which will be comprehensively reviewed below:

1) Since 2012, multiple in vitro studies have demonstrated that Ivermectin inhibits the replication of many viruses, including influenza, Zika, Dengue and others (Mastrangelo et al., 2012; Wagstaff et al., 2012; Tay et al., 2013; Götz et al., 2016; Varghese et al., 2016;Atkinson et al., 2018;Lv et al., 2018; King et al., 2020; Yang et al., 2020).

2) Ivermectin inhibits SARS-CoV-2 replication and binding to host tissue via several observed and proposed mechanisms (Caly et al., 2020a).

3) Ivermectin has potent anti-inflammatory properties with in vitro data demonstrating profound inhibition of both cytokine production and transcription of nuclear factor- $\kappa \mathrm{B}(\mathrm{NF}-\kappa \mathrm{B})$, the most potent mediator of inflammation (Zhang et al., 2008; Ci et al., 2009;Zhang et al., 2009).

4) Ivermectin significantly diminishes viral load and protects against organ damage in multiple animal models when infected with SARS-CoV-2 or similar coronaviruses (Arevalo et al., 2020; de Melo et al., 2020).

5) Ivermectin prevents transmission and development of COVID-19 disease in those exposed to infected patients (Behera et al., 2020;Bernigaud et al., 2020;Carvallo et al., 2020b;Elgazzar et al., 2020;Hellwig and Maia, 2020; Shouman, 2020).

6) Ivermectin hastens recovery and prevents deterioration in patients with mild to moderate disease treated early after symptoms (Carvallo et al., 2020a;Elgazzar et al., 2020;Gorial et al., 2020;Khan et al., 2020;Mahmud, 2020;Morgenstern et al., 2020;Robin et al., 2020).

7) Ivermectin hastens recovery and avoidance of ICU admission and death in hospitalized patients (Elgazzar et al., 2020; Hashim et al., 2020; Khan et al., 2020; Niaee et al., 2020; Portmann-Baracco et al., 2020; Rajter et al., 2020; Spoorthi V, 2020).

https://www.worldometers.info/coronavirus/country/us/ https://www.npr.org/sections/coronavirus-live-updates/2020/12/15/946644132/some-european-countries-battendown-for-the-holidays-with-new-coronavirus-lockdo

4 https://www.lilly.com/news/stories/statement-activ3-clinical-trial-nih-covid19 


\section{Efficacy of Ivermectin in COVID-19}

8) Ivermectin reduces mortality in critically ill patients with COVID-19 (Elgazzar et al., 2020; Hashim et al., 2020; Rajter et al., 2020).

9) Ivermectin leads to striking reductions in case-fatality rates in regions with widespread use (Chamie, 2020). ${ }^{5}$

10) The safety, availability, and cost of ivermectin is nearly unparalleled given its near nil drug interactions along with only mild and rare side effects observed in almost 40 years of use and billions of doses administered (Kircik et al., 2016).

11) The World Health Organization has long included ivermectin on its "List of Essential Medicines". 6

Following is a comprehensive review of the available efficacy data as of December 12, 2020, taken from in vitro, animal, clinical, and real-world studies all showing the above impacts of ivermectin in COVID-19.

\section{History of ivermectin}

In 1975, Professor Satoshi Omura at the Kitsato institute in Japan isolated an unusual Streptomyces bacteria from the soil near a golf course along the south east coast of Honshu, Japan. Omura, along with William Campbell, found that the bacterial culture could cure mice infected with the roundworm Heligmosomoides polygyrus. Campbell isolated the active compounds from the bacterial culture, naming them "avermectins" and the bacterium Streptomyces avermitilis for the compounds' ability to clear mice of worms (Crump and Omura, 2011). Despite decades of searching around the world, the Japanese microorganism remains the only source of avermectin ever found. Ivermectin, a derivative of avermectin, then proved revolutionary. Originally introduced as a veterinary drug, it soon after made historic impacts in human health, improving the nutrition, general health and well-being of billions of people worldwide ever since it was first used to treat Onchocerciasis (river blindness) in humans in 1988. It proved ideal in many ways, given that it was highly effective, broad-spectrum, safe, well tolerated and could be easily administered (Crump and Omura, 2011). Although it was used to treat a variety of internal nematode infections, it was most known as the essential mainstay of two global disease elimination campaigns that has nearly eliminated the world of two of its most disfiguring and devastating diseases. The unprecedented partnership between Merck \& Co. Inc., and the Kitasato Institute combined with the aid of international health care organizations has been recognized by many experts as one of the greatest medical accomplishments of the 20th century. One example was the decision by Merck \& Co to donate ivermectin doses to support the Meztican Donation Program which then provided over 570 million treatments in its first 20 years alone (Tambo et al.). Ivermectins' impacts in controlling Onchocerciasis and Lymphatic filariasis, diseases which blighted the lives of billions of the poor and disadvantaged throughout the tropics, is why its discoverers were awarded the Nobel Prize in Medicine in 2015 and the reason for its inclusion on the WHO's "List of Essential Medicines." Further, it has also been used to successfully overcome several other human diseases and new uses for it are continually being found (Crump and Omura, 2011).

\section{Pre-Clinical Studies of Ivermectin's activity against SARS-CoV-2}

https://trialsitenews.com/an-old-drug-tackles-new-tricks-ivermectin-treatment-in-three-brazilian-towns/ https://www.who.int/publications/i/item/WHOMVPEMPIAU201907 


\section{Efficacy of Ivermectin in COVID-19}

Since 2012, a growing number of cellular studies have demonstrated that ivermectin has anti-viral properties against an increasing number of RNA viruses, including influenza, Zika, HIV, Dengue, and most importantly, SARS-CoV-2 (Mastrangelo et al., 2012;Wagstaff et al., 2012;Tay et al., 2013; Götz et al., 2016; Varghese et al., 2016;Atkinson et al., 2018;Lv et al., 2018;King et al., 2020; Yang et al., 2020). Insights into the mechanisms of action by which ivermectin both interferes with the entrance and replication of SARS-CoV-2 within human cells are mounting. Caly et al first reported that ivermectin significantly inhibits SARS-CoV-2 replication in a cell culture model, observing the near absence of all viral material $48 \mathrm{~h}$ after exposure to ivermectin (Caly et al., 2020b). However, some questioned whether this observation is generalizable clinically given the inability to achieve similar tissue concentrations employed in their experimental model using standard or even massive doses of ivermectin (Bray et al., 2020;Schmith et al., 2020). It should be noted that the concentrations required for effect in cell culture models bear little resemblance to human physiology given the absence of an active immune system working synergistically with a therapeutic agent such as ivermectin. Further, prolonged durations of exposure to a drug likely would require a fraction of the dosing in short term cell model exposure. Further, multiple co-existing or alternate mechanisms of action likely explain the clinical effects observed, such as the competitive binding of ivermectin with the host receptor-binding region of SARS-CoV-2 spike protein, as proposed in six molecular modeling studies (Dayer, 2020;Hussien and Abdelaziz, 2020;Lehrer and Rheinstein, 2020;Maurya, 2020; Nallusamy et al., 2020; Suravajhala et al., 2020). In four of the studies, ivermectin was identified as having the highest or among the highest of binding affinities to spike protein S1 binding domains of SARS-CoV-2 among hundreds of molecules collectively examined, with ivermectin not being the particular focus of study in four of these studies (Scheim, 2020). This is the same mechanism by which viral antibodies, in particular, those generated by the Pfizer and Moderna vaccines, contain the SARS-CoV-2 virus. The high binding activity of ivermectin to the SARS-CoV2 spike protein could limit binding to either the ACE-2 receptor or sialic acid receptors, respectively either preventing cellular entry of the virus or preventing hemagglutination, a recently proposed pathologic mechanism in COVID-19 (Dasgupta J, 2020;Dayer, 2020;Lehrer and Rheinstein, 2020; Maurya, 2020;Scheim, 2020). Ivermectin has also been shown to bind to or interfere with multiple essential structural and non-structural proteins required by the virus in order to replicate (Lehrer and Rheinstein, 2020;Sen Gupta et al., 2020). Finally, ivermectin also binds to the SARSCoV-2 RNA-dependent RNA polymerase (RdRp), thereby inhibiting viral replication (Swargiary, 2020).

Arevalo et al investigated in a murine model infected with a type 2 family RNA coronavirus similar to SARS-CoV-2, (mouse hepatitis virus), the response to $500 \mathrm{mcg} / \mathrm{kg}$ of ivermectin vs. placebo (Arevalo et al., 2020). The study included 40 infected mice, with 20 treated with ivermectin, 20 with phosphate buffered saline, and then 16 uninfected control mice that were also given phosphate buffered saline. At day 5, all the mice were euthanized to obtain tissues for examination and viral load assessment. The 20 non-ivermectin treated infected mice all showed severe hepatocellular necrosis surrounded by a severe lymphoplasmacytic inflammatory infiltration associated with a high hepatic viral load $(52,158 \mathrm{AU})$, while in the ivermectin treated mice a much lower viral load was measured $(23,192 \mathrm{AU} ; \mathrm{p}<0.05)$, with only few livers in the ivermectin treated mice showing histopathological damage such that the differences between the livers from the uninfected control mice were not statistically significant.

Dias De Melo and colleagues recently posted the results of a study they did with golden hamsters that were intranasally inoculated with SARS-CoV-2 virus, and at the time of the infection, the animals also received a single subcutaneous injection of ivermectin at a dose of $0.4 \mathrm{mg} / \mathrm{kg}$ on day 1 (de Melo et al., 2020). Control animals received only the physiologic solution. They found the following among the ivermectin treated hamsters; a dramatic reduction in anosmia $(33.3 \% \mathrm{vs} 83.3 \%$, $\mathrm{p}=.03)$ which was also sex-dependent in that the male hamsters exhibited a reduction in clinical score 


\section{Efficacy of Ivermectin in COVID-19}

while the treated female hamsters failed to show any sign of anosmia. They also found significant reductions in cytokine concentrations in the nasal turbinate's and lungs of the treated animals despite the lack of apparent differences in viral titers.

Despite these mounting insights into the existing and potential mechanisms of action of ivermectin both as a prophylactic and treatment agent, it must be emphasized that significant research gaps remain and that many further in vitro and animal studies should be undertaken to better define not only these mechanisms but also to further support ivermectin's role as a prophylactic agent, especially in terms of the optimal dose and frequency required.

\section{Pre-Clinical studies of ivermectin's anti-inflammatory properties}

Given that little viral replication occurs in the later phases of COVID-19, nor can virus be cultured, and only in a minority of autopsies can viral cytopathic changes be found (Perera et al., 2020;Polak et al., 2020; Young et al., 2020), the most likely pathophysiologic mechanism is that identified by Li et al. where they showed that the non-viable RNA fragments of SARS-CoV-2 leads to a high mortality and morbidity in COVID-19 via the provocation of an overwhelming and injurious inflammatory response (Li et al., 2013). Based on these insights and the clinical benefits of ivermectin in late phase disease to be reviewed below, it appears that the increasingly well described in vitro properties of ivermectin as an inhibitor of inflammation are far more clinically potent than previously recognized. The growing list of studies demonstrating the anti-inflammatory properties of ivermectin include its ability to; inhibit cytokine production after lipopolysaccharide exposure, downregulate transcription of NF-kB, and limit the production of both nitric oxide and prostaglandin $\mathrm{E}_{2}$ (Zhang et al., 2008; Ci et al., 2009; Zhang et al., 2009).

\section{Exposure prophylaxis studies of ivermectin's ability to prevent transmission of COVID-19}

Data is also now available showing large and statistically significant decreases in the transmission of COVID-19 among human subjects based on data from three randomized controlled trials (RCT) and five observational controlled trials (OCT) with four of the eight (two of them RCT's) published in peer-reviewed journals (Behera et al., 2020;Bernigaud et al., 2020; Carvallo et al., 2020b; Chala, 2020;Elgazzar et al., 2020;Hellwig and Maia, 2020;Shouman, 2020).

Elgazzar and colleagues at Benha University in Egypt randomized 200 health care and households contacts of COVID-19 patients where the intervention group consisted of 100 patients given a high dose of $0.4 \mathrm{mg} / \mathrm{kg}$ on day 1 and a second dose on day 7 in addition to wearing personal protective equipment (PPE), while the control group of 100 contacts wore PPE only (Elgazzar et al., 2020). They reported a large and statistically significant reduction in contacts testing positive by RTPCR when treated with ivermectin vs. controls, $2 \%$ vs $10 \%, \mathrm{p}<.05$.

Shouman conducted an RCT at Zagazig University in Egypt, including 340 (228 treated, 112 control) family members of patients positive for SARS-CoV-2 via PCR (Shouman, 2020).

Ivermectin, (approximately $0.25 \mathrm{mg} / \mathrm{kg}$ ) was administered twice, on the day of the positive test and 72 hours later. After a two-week follow up, a large and statistically significant decrease in COVID-19 symptoms among household members treated with ivermectin was found, $7.4 \%$ vs. $58.4 \%, p<.001$.

Recently Alam et al from Bangladesh performed a prospective observational study of 118 patients that were evenly split into those that volunteered for either the treatment or control arms, described as a persuasive approach. Although this method, along with the study being unblinded likely led to confounders, the differences between the two groups were so large $(6.7 \% \mathrm{vs} .73 .3 \%, \mathrm{p}$ $<.001$ ) and similar to the other prophylaxis trial results that confounders alone are unlikely to explain 


\section{Efficacy of Ivermectin in COVID-19}

such a result (Alam et al., 2020). Carvallo et al also performed a prospective observational trial where they gave healthy volunteers ivermectin and carrageenan daily for 28 days and matched them to similarly healthy controls who did not take the medicines (Carvallo et al., 2020b). Of the 229 study subjects, 131 were treated with $0.2 \mathrm{mg}$ of ivermectin drops taken by mouth five times per day. After 28 days, none of those receiving ivermectin prophylaxis group had tested positive for SARS-COV-2 versus $11.2 \%$ of patients in the control arm $(\mathrm{p}<.001)$. In a much larger follow-up observational controlled trial by the same group that included 1,195 health care workers, they found that over a 3month period, there were no infections recorded among the 788 workers that took weekly ivermectin prophylaxis while $58 \%$ of the 407 controls had become ill with COVID-19. This study demonstrates that protection against transmission can be achieved among high-risk health care workers by taking $12 \mathrm{mg}$ once weekly (Carvallo et al., 2020b). The Carvallo IVERCAR protocol was also separately tested in a prospective RCT by the Health Ministry of Tucuman, Argentina where they found that among 234 health care workers, the intervention group that took $12 \mathrm{mg}$ once weekly, only $3.4 \%$ contracted COVID-19 vs. $21.4 \%$ of controls, $p<.0001$ (Chala, 2020).

The need for weekly dosing in the Carvallo study over a 4 month period may not have been necessary given that, in a recent RCT from Dhaka, Bangladesh, the intervention group $(n=58)$ took $12 \mathrm{mg}$ only once monthly for a similar 4 month period and also reported a large and statistically significant decrease in infections compared to controls, 6.9\% vs. 73.3\%, p<.05 (Alam et al., 2020). Then, in a large retrospective observational case-control study from India, Behera et al. reported that among 186 case-control pairs $(n=372)$ of health care workers, they identified 169 participants that had taken some form of prophylaxis, with 115 that had taken ivermectin prophylaxis (Behera et al., 2020). After matched pair analysis, they reported that in the workers who had taken two dose ivermectin prophylaxis, the odds ratio for contracting COVID-19 was markedly decreased (0.27, 95\% CI, 0.15-0.51). Notably, one dose prophylaxis was not found to be protective in this study. Based on both their study finding and the Egyptian prophylaxis study, the All-India Institute of Medical Sciences instituted a prophylaxis protocol for their health care workers where they now take two $0.3 \mathrm{mg} / \mathrm{kg}$ doses of ivermectin 72 hours apart and repeat the dose monthly.

Data which further illuminates the protective role of ivermectin against COVID-19 comes from a study of nursing home residents in France which reported that in a facility that suffered a scabies outbreak where all 69 residents and 52 staff were treated with ivermectin (Behera et al., 2020), they found that during the time period surrounding this event, 7/69 residents fell ill with COVID-19 (10.1\%). In this group with an average age of 90 years, only one resident required oxygen support and no resident died. In a matched control group of residents from surrounding facilities, they found $22.6 \%$ of residents fell ill and $4.9 \%$ died.

Likely the most definitive evidence supporting the efficacy of ivermectin as a prophylaxis agent was published recently in the International Journal of Anti-Microbial agents where a group of researchers analyzed data using the prophylactic chemotherapy databank administered by the WHO along with case counts obtained by Worldometers, a public data aggregation site used by among others, the Johns Hopkins University (Hellwig and Maia, 2020). When they compared the data from countries with active ivermectin mass drug administration programs for the prevention of parasite infections, they discovered that the COVID-19 case counts were significantly lower in the countries with recently active programs, to a high degree of statistical significance, $p<.001$.

Figure 1 below presents a meta-analysis performed by the study authors of the controlled ivermectin prophylaxis trials in COVID-19. 
Efficacy of Ivermectin in COVID-19

Figure 1. Meta-analysis of ivermectin prophylaxis trials in COVID-19

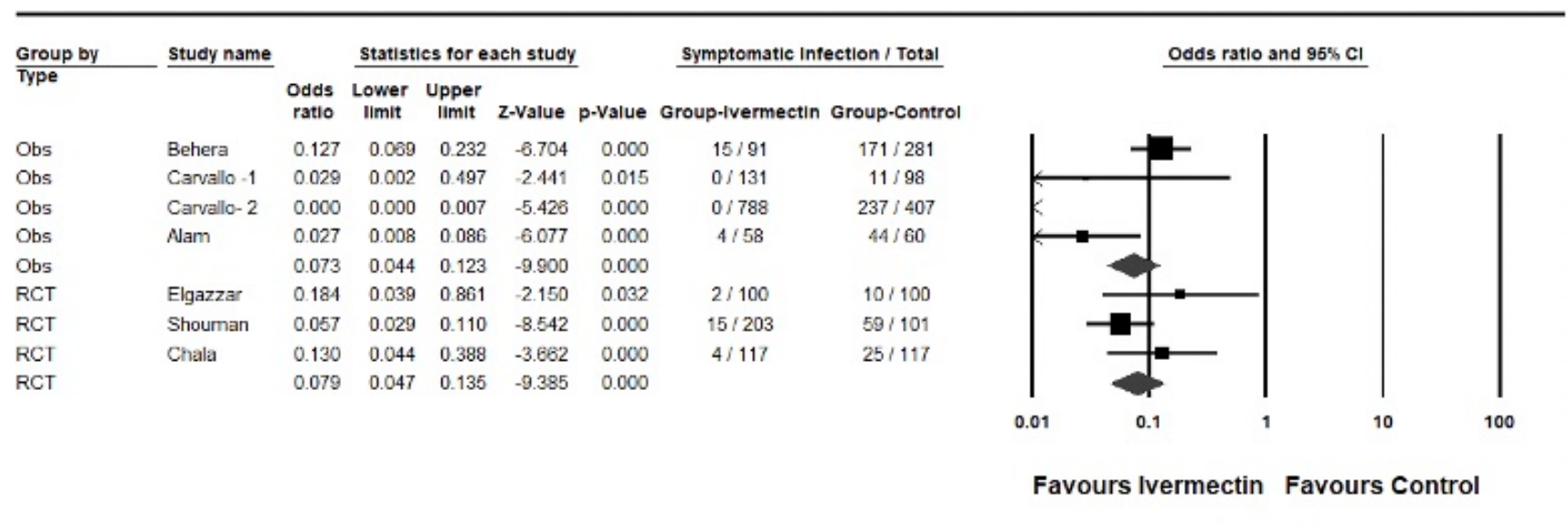

Figure 1 legend: OBS: Observational study, RCT: Randomized Controlled Trial Symbols: Squares: indicate treatment effect of an individual study. Large diamond: reflect summary of study design immediately above. Small diamond: sum effect of all trial designs. Size of each symbol correlates with the size of the confidence interval around the point estimate of treatment effect with larger sizes indicating a more precise confidence interval.

Further data supporting a role for ivermectin in decreasing transmission rates can be found from South American countries where, in retrospect, large "natural experiments" appear to have occurred. For instance, beginning as early as May, various regional health ministries and governmental authorities within Peru, Brazil, and Paraguay initiated "ivermectin distribution" campaigns to their citizen populations (Chamie, 2020). In one such example from Brazil, the cities of Itajai, Macapa, and Natal distributed massive amounts of ivermectin doses to their city's population, where, in the case of Natal, 1 million doses were distributed. ${ }^{7}$ The distribution campaign of Itajai began in mid-July, and in Natal they began on June $30^{\text {th }}$, and in Macapa, the capital city of Amapa and others nearby incorporated ivermectin into their treatment protocols in late May after they were particularly hard hit in April. The data in Table 1 below was obtained from the official Brazilian government site and the national press consortium and show large decreases in case counts in the three cities soon after distribution began compared to their neighboring cities without such campaigns.

The decreases in case counts among the three Brazilian cities shown in Table 1 was also associated with reduced mortality rates as seen in Table 2 below.

7 https://trialsitenews.com/an-old-drug-tackles-new-tricks-ivermectin-treatment-in-three-brazilian-towns/ 
Table 1. Comparison of case count decreases among Brazilian cities with and without ivermectin distribution campaigns (bolded cities distributed ivermectin, neighboring regional city below did not)

\begin{tabular}{lllllcc}
\hline REGION & NEW CASES & JUNE & JULY & AUGUST & $\begin{array}{c}\text { POPULATION } \\
2020(1000)\end{array}$ & $\begin{array}{c}\text { \% DECLINE IN NEW } \\
\text { CASES BETWEEN JUNE } \\
\text { AND AUGUST 2020 }\end{array}$ \\
\hline \multirow{2}{*}{ South } & Itajaí & $\mathbf{2 1 2 3}$ & $\mathbf{2 8 5 4}$ & $\mathbf{9 9 8}$ & $\mathbf{2 2 3}$ & $-\mathbf{5 3 \%}$ \\
& Chapecó & 1760 & 1754 & 1405 & 224 & $-20 \%$ \\
\hline \multirow{2}{*}{ North } & Macapá & $\mathbf{7 9 6 6}$ & $\mathbf{2 4 8 1}$ & $\mathbf{2 3 7 0}$ & $\mathbf{5 0 3}$ & $-\mathbf{7 0} \%$ \\
& Ananindeua & 1520 & 1521 & 1014 & 535 & $-30 \%$ \\
\hline \multirow{2}{*}{ North East } & Natal & $\mathbf{9 0 0 9}$ & $\mathbf{7 5 5 4}$ & $\mathbf{1 5 9 0}$ & $\mathbf{8 9 0}$ & $-\mathbf{8 2} \%$ \\
& João Pessoa & 9437 & 7963 & 5384 & 817 & $-43 \%$ \\
\hline
\end{tabular}

Table 2. Change in death rates among neighboring regions in Brazil (bolded regions contained a major city that distributed Ivermectin to its citizens, the other regions did not)

\begin{tabular}{llc}
\hline REGION & STATE & $\begin{array}{c}\text { \% CHANGE IN AVERAGE DEATHS/ } \\
\text { WEEK COMPARED TO 2 WEEKS PRIOR }\end{array}$ \\
\hline South & Santa Catarina & $-\mathbf{3 6} \%$ \\
& PARANÁ & $-3 \%$ \\
& Rio Grande do Sul & $-5 \%$ \\
North & Amapá & $-\mathbf{7 5 \%}$ \\
& AMAZONAS & $-42 \%$ \\
North East & Pará & $+13 \%$ \\
& Rio Grande do Norte & $-\mathbf{6 5 \%}$ \\
& CEARÁ & $+62 \%$ \\
& Paraíba & $-30 \%$ \\
\hline
\end{tabular}

\section{Clinical studies on the efficacy of ivermectin in treating mildly ill outpatients}

Currently, seven trials which include a total of over 3,000 patients with mild outpatient illness have been completed, a set comprised of 7 RCT's and four case series (Babalola et al.;Cadegiani et al., 2020; Carvallo et al., 2020a; Chaccour et al., 2020;Chowdhury et al., 2020;Espitia-Hernandez et al., 2020; Gorial et al., 2020;Hashim et al., 2020;Khan et al., 2020;Mahmud, 2020;Podder et al., 2020; Ravikirti et al., 2021). 


\section{Efficacy of Ivermectin in COVID-19}

The largest, a double blinded RCT by Mahmud et al. was conducted in Dhaka, Bangladesh and targeted 400 patients with 363 patients completing the study (Mahmud, 2020). In this study, as in many other of the clinical studies to be reviewed, either a tetracycline (doxycycline) or macrolide antibiotic (azithromycin) was included as part of the treatment. The importance of including antibiotics such as doxycycline or azithromycin is unclear, however, both tetracycline and macrolide antibiotics have recognized anti-inflammatory, immunomodulatory, and even antiviral effects (5861). Although the posted data from this study does not specify the amount of mildly ill outpatients vs. hospitalized patients treated, important clinical outcomes were profoundly impacted, with increased rates of early improvement $(60.7 \%$ vs. $44.4 \% \mathrm{p}<.03)$ and decreased rates of clinical deterioration $(8.7 \%$ vs $17.8 \%, p<.02)$. Given that mildly ill outpatients mainly comprised the study cohort, only two deaths were observed (both in the control group).

Ravikirti performed a double-blind RCT of 115 patients, ang although the primary outcome of PCR positivity on Day 6 was no different, the secondary outcome of mortality was $0 \% \mathrm{vs} .6 .9 \%$, $\mathrm{p}=.019$ (Ravikirti et al., 2021). Babalola in Nigeria also performed a double blind-RCT of 62 patients, and, in contrast to Ravikirti, they found a significant difference in viral clearance between both the low and high dose treatment groups and controls in a dose dependent fashion, $\mathrm{p}=.006$ (Babalola et al.).

Another RCT by Hashim et al. in Baghdad, Iraq included 140 patients equally divided; the control group received standard care, the treated group included a combination of both outpatient and hospitalized patients (Hashim et al., 2020). In the 96 patients with mild-to-moderate outpatient illness, they treated 48 patients with a combination of ivermectin/doxycycline and standard of care and compared outcomes to the 48 patients treated with standard of care alone. The standard of care in this trial included many elements of the MATH+ protocol, such as dexamethasone $6 \mathrm{mg} /$ day or methylprednisolone 40mg twice per day if needed, Vitamin C 1000mg twice/day, Zinc 75$125 \mathrm{mg}$ /day, Vitamin D3 $5000 \mathrm{IU} /$ day, azithromycin 250mg/day for 5 days, and acetaminophen $500 \mathrm{mg}$ as needed. Although no patients in either group progressed or died, the time to recovery was significantly shorter in the ivermectin treated group (6.3 days vs 13.7 days, $\mathrm{p}<.0001)$.

Chaccour et al conducted a small, double-blinded RCT in Spain where they randomized 24 patients to ivermectin vs placebo and although they found no difference in PCR positivity at day 7 , they did find statistically significant decreases in viral loads, patient days of anosmia (76 vs 158, $\mathrm{p}<.05$ ), and patient days with cough (68 vs 98, p<.05) (Chaccour et al., 2020).

Another RCT of ivermectin treatment in 116 outpatients was performed by Chowdhury et al. in Bangladesh where they compared a group of 60 patients treated with the combination of ivermectin/doxycycline to a group of 60 patients treated with hydroxychloroquine/doxycycline with a primary outcome of time to negative PCR (Chowdhury et al., 2020). Although they found no difference in this outcome, in the treatment group, the time to symptomatic recovery approached statistical significance (5.9 days vs. 7.0 days, $\mathrm{p}=.07$ ). In another smaller RCT of 62 patients by Podder et al., they also found a shorter time to symptomatic recovery that approached statistical significance (10.1 days vs 11.5 days, $\mathrm{p}>.05,95 \%$ CI, 0.86-3.67) (Podder et al., 2020).

A medical group in the Dominican Republic reported a case series of 2,688 consecutive symptomatic outpatients seeking treatment in the emergency room, the majority of whom were diagnosed using a clinical algorithm. The patients were treated with high dose ivermectin of $0.4 \mathrm{mg} / \mathrm{kg}$ for one dose along with five days of azithromycin. Only 16 of the 2,688 patients $(0.59 \%)$ required subsequent hospitalization with one death recorded (Morgenstern et al., 2020).

In another case series of 100 patients in Bangladesh, all treated with a combination of $0.2 \mathrm{mg} / \mathrm{kg}$ ivermectin and doxycycline, they found that no patient required hospitalization nor died, and all patients' symptoms improved within 72 hours (Robin et al., 2020).

A case series from Argentina reported on a combination protocol which used ivermectin, aspirin, dexamethasone and enoxaparin. In the 135 mild illness patients, all survived (Carvallo et al., 


\section{Efficacy of Ivermectin in COVID-19}

2020a). Similarly, a case series from Mexico of 28 consecutively treated patients with ivermectin, all were reported to have recovered with an average time to full recovery of only 3.6 days (EspitiaHernandez et al., 2020).

\section{Clinical studies of the efficacy of ivermectin in hospitalized patients}

Studies of ivermectin amongst more severely ill hospitalized patients include 6 RCT's, 5 OCTs, and a database analysis study (Ahmed et al., 2020;Budhiraja et al., 2020; Chachar et al., 2020;Elgazzar et al., 2020; Gorial et al., 2020; Hashim et al., 2020; Khan et al., 2020; Niaee et al., 2020;PortmannBaracco et al., 2020; Rajter et al., 2020; Soto-Becerra et al., 2020; Spoorthi V, 2020).

The largest RCT in hospitalized patients was performed concurrent with the prophylaxis study reviewed above by Elgazzar et al (Elgazzar et al., 2020). 400 patients were randomized amongst 4 treatment groups of 100 patients each. Groups 1 and 2 included mild/moderate illness patients only, with Group 1 treated with one dose $0.4 \mathrm{mg} / \mathrm{kg}$ ivermectin plus standard of care (SOC) and Group 2 received hydroxychloroquine (HCQ) 400mg twice on day 1 then 200mg twice daily for 5 days plus standard of care. There was a statistically significant lower rate of progression in the ivermectin treated group ( $1 \%$ vs. $22 \%, p<.001)$ with no deaths and 4 deaths respectively. Groups 3 and 4 all included only severely ill patients, with group 3 again treated with single dose of $0.4 \mathrm{mg} / \mathrm{kg}$ plus SOC while Group 4 received HCQ plus SOC. In this severely ill subgroup, the differences in outcomes were even larger, with lower rates of progression $4 \%$ vs. $30 \%$, and mortality $2 \%$ vs $20 \%$ $(\mathrm{p}<.001)$.

The one largely outpatient RCT done by Hashim reviewed above also included 22 hospitalized patients in each group. In the ivermectin/doxycycline treated group, there were 11 severely ill patients and 11 critically ill patients while in the standard care group, only severely ill patients $(n=22)$ were included due to their ethical concerns of including critically ill patients in the control group (45). This decision led to a marked imbalance in the severity of illness between these hospitalized patient groups. However, despite the mismatched severity of illness between groups and the small number of patients included, beneficial differences in outcomes were seen, but not all reached statistical significance. For instance, there was a large reduction in the rate of progression of illness $(9 \%$ vs. $31.8 \%, p=0.15)$ and, most importantly, there was a large difference in mortality amongst the severely ill groups which reached a borderline statistical significance, $(0 \%$ vs $27.3 \%$, p $=.052$ ). Another important finding was the surprisingly low mortality rate of $18 \%$ found among the subset of critically ill patients, all of whom were treated with ivermectin.

A recent RCT from Iran found a dramatic reduction in mortality with ivermectin use (Niaee et al., 2020). Among multiple ivermectin treatment arms (different ivermectin dosing strategies were used in the intervention arms), the average mortality was reported as $3.3 \%$ while the average mortality within the standard care and placebo arms was $18.8 \%$, with an OR of 0.18 (95\% CI 0.06 $0.55, \mathrm{p}<.05)$.

Spoorthi and Sasanak performed a prospective RCT of 100 hospitalized patients whereby they treated 50 with ivermectin and doxycycline while the 50 controls were given a placebo consisting of Vitamin B6 (Spoorthi V, 2020). Although no deaths were reported in either group, the ivermectin treatment group had a shorter hospital LOS 3.7 days vs 4.7 days, $p=.03$, and a shorter time to complete resolution of symptoms, 6.7 days vs 7.9 days, $\mathrm{p}=.01$.

The largest OCT $(\mathrm{n}=280)$ in hospitalized patients was done by Rajter et al. at Broward Health Hospitals in Florida and was recently published in the major medical journal Chest (43). They performed a retrospective OCT with a propensity matched design on 280 consecutive treated patients and compared those treated with ivermectin to those without. 173 patients were treated with ivermectin (160 received a single dose, 13 received a $2^{\text {nd }}$ dose at day 7) while 107 were not (Rajter et 


\section{Efficacy of Ivermectin in COVID-19}

al., 2020). In both unmatched and propensity matched cohort comparisons, similar, large, and statistically significant lower mortality was found amongst ivermectin treated patients $(15.0 \%$ vs. $25.2 \%$, p $=.03$ ). Further, in the subgroup of patients with severe pulmonary involvement, mortality was profoundly reduced when treated with ivermectin $(38.8 \%$ vs. $80.7 \%, \mathrm{p}=.001)$.

Another large OCT in Bangladesh compared 115 pts treated with ivermectin to a standard care cohort consisting of 133 patients (Khan et al., 2020). Despite a significantly higher proportion of patients in the ivermectin group being male (i.e., with well-described, lower survival rates in COVID), the groups were otherwise well matched, yet the mortality decrease was statistically significant $(0.9 \%$ vs. $6.8 \%, \mathrm{p}<.05)$. The largest OCT is a study from Brazil which included almost 1,500 patients (Portmann-Baracco et al., 2020). Although the primary data was not provided, they reported that in 704 hospitalized patients treated with a single dose of $0.15 \mathrm{mg} / \mathrm{kg}$ ivermectin compared to 704 controls, overall mortality was reduced ( $1.4 \%$ vs. $8.5 \%$, HR $0.2,95 \%$ CI $0.12-0.37$, $\mathrm{p}<.0001)$. Similarly, in the patients on mechanical ventilation, mortality was also reduced $(1.3 \% \mathrm{vs}$. 7.3\%). A small study from Baghdad, Iraq compared 16 ivermectin treated patients to 71 controls (Gorial et al., 2020). This study also reported a significant reduction in length of hospital stay (7.6 days vs. 13.2 days, $p<.001$ ) in the ivermectin group. In a study reporting on the first 1000 patients treated in a hospital in India, they found that in the 34 patients treated with ivermectin alone, all recovered and were discharged, while in the over 900 patients treated with other agents, there was an overall mortality of $11.1 \%$ (Budhiraja et al., 2020).

One retrospective analysis of a database of hospitalized patients compared responses in patients receiving ivermectin, azithromycin, hydroxychloroquine or combinations of these medicines. In this study, no benefit for ivermectin was found, however the treatment groups in this analysis all included a number of patients who died on day 2 , while in the control groups no early deaths occurred, thus the comparison appears limited (Soto-Becerra et al., 2020).

Meta-analyses of the above controlled treatment trials were performed by the study authors focused on the two important clinical outcomes: time to clinical recovery and mortality (Figures 2 and 3). The consistent and reproducible signals leading to large overall statistically significant benefits from within both study designs is remarkable, especially given that in several of the studies treatment was initiated late in the disease course. 
Figure 2. Meta-analysis of the outcome of time to clinical recovery from randomized controlled trials of ivermectin treatment in COVID-19

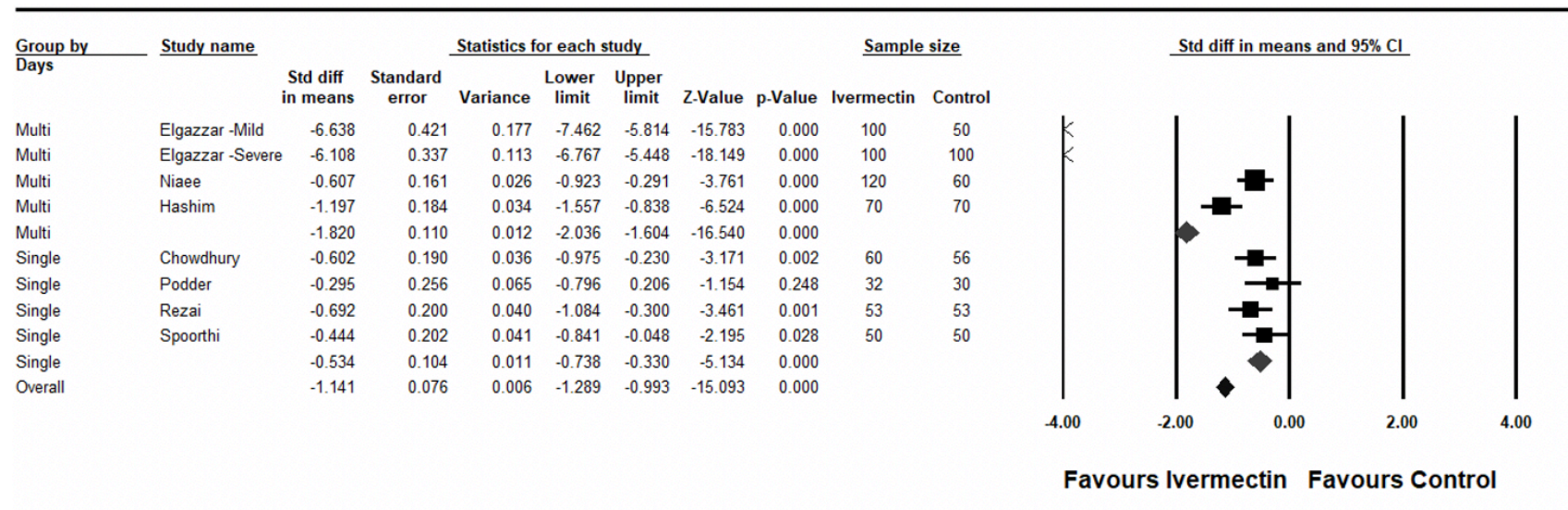

Figure 2 legend: Multi: multiple day dosing regimen. Single: single dose regimen Symbols: Squares: indicate treatment effect of an individual study. Large diamond: reflect summary of study design immediately above. Small diamond: sum effect of all trial designs. Size of each symbol correlates with the size of the confidence interval around the point estimate of treatment effect with larger sizes indicating a more precise confidence interval.

Figure 3. Meta-analysis of the outcome of mortality from controlled trials of ivermectin treatment in COVID-19

\begin{tabular}{|c|c|c|c|c|c|c|c|c|}
\hline \multirow{2}{*}{$\frac{\text { Group by }}{\text { RCT-Obs }}$} & \multirow[t]{2}{*}{$\underline{\text { Study name }}$} & \multicolumn{5}{|c|}{ Statistics for each study } & \multicolumn{2}{|c|}{ Dead / Total } \\
\hline & & $\begin{array}{l}\text { Odds } \\
\text { ratio }\end{array}$ & $\begin{array}{l}\text { Lower } \\
\text { limit }\end{array}$ & $\begin{array}{l}\text { Upper } \\
\text { limit }\end{array}$ & Z-Value & p-Value & Ivermectin & Control \\
\hline OBS & Rajter & 0.524 & 0.287 & 0.958 & -2.099 & 0.036 & $26 / 173$ & $27 / 107$ \\
\hline OBS & Khan & 0.121 & 0.015 & 0.969 & -1.990 & 0.047 & $1 / 115$ & $9 / 133$ \\
\hline OBS & Gorial & 0.842 & 0.039 & 18.393 & -0.109 & 0.913 & $0 / 16$ & $2 / 71$ \\
\hline OBS & Budhiraja & 0.118 & 0.007 & 1.932 & -1.499 & 0.134 & $0 / 34$ & $103 / 942$ \\
\hline OBS & & 0.451 & 0.258 & 0.789 & -2.793 & 0.005 & & \\
\hline RCT & Mahmud & 0.138 & 0.007 & 2.694 & -1.306 & 0.192 & $0 / 183$ & $3 / 180$ \\
\hline $\mathrm{RCT}$ & Hashim & 0.314 & 0.061 & 1.611 & -1.389 & 0.165 & $2 / 70$ & $6 / 70$ \\
\hline RCT & Elgazzar & 0.074 & 0.017 & 0.318 & -3.502 & 0.000 & $2 / 200$ & $24 / 200$ \\
\hline RCT & Niaee & 0.154 & 0.047 & 0.506 & -3080 & 0.002 & $4 / 120$ & $11 / 60$ \\
\hline $\mathrm{RCT}$ & Cadegiani & 0.046 & 0.002 & 0.970 & -1.980 & 0.048 & $0 / 585$ & $2 / 137$ \\
\hline RCT & Ravikirt & 0.107 & 0.008 & $2.03 \mathrm{~B}$ & -1.486 & 0.137 & $0 / 55$ & $4 / 57$ \\
\hline RCT & & 0.134 & 0065 & 0.277 & -5413 & 0000 & & \\
\hline Overall & & 0.288 & 0.185 & 0.448 & -5.509 & 0.000 & & \\
\hline
\end{tabular}

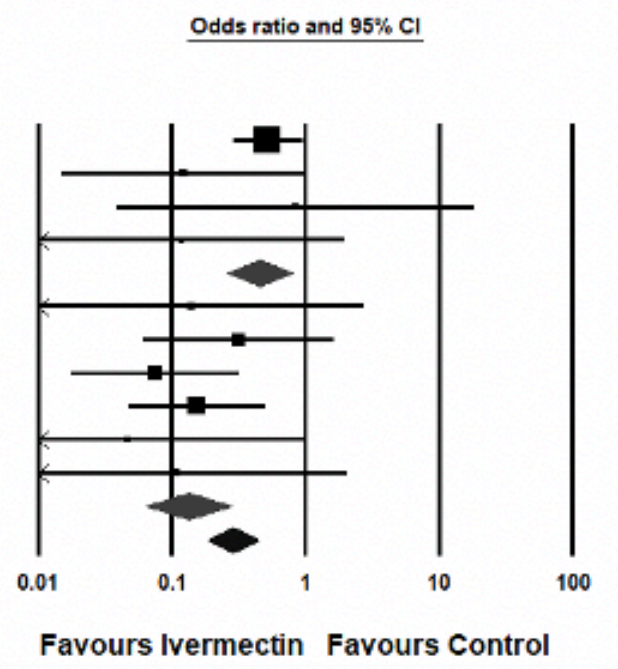

Figure 3 legend: OBS: Observational study, RCT: Randomized Controlled Trial. Symbols: Squares: indicate treatment effect of an individual study. Large diamond: reflect summary of study design immediately above. Small diamond: sum effect of all trial designs. Size of each symbol correlates with the size of the confidence interval around the point estimate of treatment effect with larger sizes indicating a more precise confidence interval.

Details of the prophylaxis, early, and late treatment trials of ivermectin in COVID-19 can be found in Table 3 below. 
Table 3. Clinical studies assessing the efficacy of ivermectin in the prophylaxis and treatment of COVID-19

\begin{tabular}{|c|c|c|c|c|c|}
\hline \multicolumn{6}{|l|}{ Prophylaxis Trials } \\
\hline AUTHOR, COUNTRY, SOURCE & $\begin{array}{l}\text { STUDY DESIGN, } \\
\text { SIZE }\end{array}$ & $\begin{array}{l}\text { STUDY } \\
\text { SUBJECTS }\end{array}$ & $\begin{array}{l}\text { IVERMECTIN } \\
\text { DOSE }\end{array}$ & $\begin{array}{l}\text { DOSE } \\
\text { FREQUENCY }\end{array}$ & $\begin{array}{l}\text { CLINICAL } \\
\text { OUTCOMES } \\
\text { REPORTED }\end{array}$ \\
\hline $\begin{array}{l}\text { Shouman W, Egypt } \\
\text { www.clinicaltrials.gov } \\
\text { NCT04422561 }\end{array}$ & $\begin{array}{l}\mathrm{RCT} \\
\mathrm{N}=340\end{array}$ & $\begin{array}{l}\text { Household } \\
\text { members of pts } \\
\text { with +COVID- } \\
19 \text { PCR test }\end{array}$ & $\begin{array}{l}\text { 40-60kg: } 15 \mathrm{mg} \\
60-80 \mathrm{~kg}: 18 \mathrm{mg} \\
\text { > 80kg: } 24 \mathrm{mg}\end{array}$ & $\begin{array}{l}\text { Two doses, } 72 \\
\text { hours apart }\end{array}$ & $\begin{array}{l}7.4 \% \text { vs. } 58.4 \% \\
\text { developed COVID-19 } \\
\text { symptoms, } \quad \mathrm{p}<.001\end{array}$ \\
\hline $\begin{array}{l}\text { Elgazzar A, Egypt } \\
\text { ResearchSquare } \\
\text { doi.org/10.21203/rs.3.rs-100956/v1 }\end{array}$ & $\begin{array}{l}\mathrm{RCT} \\
\mathrm{N}=200\end{array}$ & $\begin{array}{l}\text { Health care and } \\
\text { Household } \\
\text { contacts of pts } \\
\text { with +COVID- } \\
19 \text { PCR test }\end{array}$ & $0.4 \mathrm{mg} / \mathrm{kg}$ & $\begin{array}{l}\text { Two doses, Day } \\
1 \text { and Day } 7\end{array}$ & $\begin{array}{l}2 \% \text { vs. } 10 \% \text { tested } \\
\text { positive for COVID- } \\
19 \mathrm{p}<.05\end{array}$ \\
\hline $\begin{array}{l}\text { Chala R. Argentina } \\
\text { NCT04701710 } \\
\text { Clinicaltrials.gov }\end{array}$ & $\begin{array}{l}\mathrm{RCT} \\
\mathrm{N}=234\end{array}$ & $\begin{array}{l}\text { Health Care } \\
\text { Workers }\end{array}$ & $12 \mathrm{mg}$ & Every 7 days & $\begin{array}{l}3.4 \% \text { vs. } 21.4 \% \\
p=.0001\end{array}$ \\
\hline $\begin{array}{l}\text { Carvallo H, Argentina } \\
\text { Journal of Biochemical Research and } \\
\text { Investigation } \\
\text { doi.org/10.31546/2633-8653.1007 }\end{array}$ & $\begin{array}{l}\text { OCT } \\
\mathrm{N}=229\end{array}$ & $\begin{array}{l}\text { Healthy patients } \\
\text { negative for } \\
\text { COVID-19 PCR }\end{array}$ & $0.2 \mathrm{mg}$ drops & $\begin{array}{l}1 \text { drop five times } \\
\text { a day } \mathrm{x} 28 \text { days }\end{array}$ & $\begin{array}{l}0.0 \% \text { vs. } 11.2 \% \\
\text { contracted COVID- } 19 \\
\text { p }<.001\end{array}$ \\
\hline $\begin{array}{l}\text { Alam MT. Bangladesh } \\
\text { European J Med Hlth Sciences } \\
\text { 10.24018/ejmed.2020.2.6.599 }\end{array}$ & $\begin{array}{l}\text { OCT } \\
\mathrm{N}=118\end{array}$ & $\begin{array}{l}\text { Health Care } \\
\text { Workers }\end{array}$ & $12 \mathrm{mg}$ & Monthly & $6.9 \%$ vs. $73.3 \%, \mathrm{p}<.05$ \\
\hline $\begin{array}{l}\text { Carvallo H. Argentina } \\
\text { Journal of Biochemical Research and } \\
\text { Investigation } \\
\text { doi.org/10.31546/2633-8653.1007 }\end{array}$ & $\begin{array}{l}\text { OCT } \\
\mathrm{N}=1,195\end{array}$ & $\begin{array}{l}\text { Health Care } \\
\text { Workers }\end{array}$ & $12 \mathrm{mg}$ & $\begin{array}{l}\text { Once weekly for } \\
\text { up to ten weeks }\end{array}$ & $\begin{array}{l}0.0 \% \text { of the } 788 \\
\text { workers taking } \\
\text { ivermectin vs. } 58 \% \text { of } \\
\text { the } 407 \text { controls } \\
\text { contracted COVID- } 19 .\end{array}$ \\
\hline $\begin{array}{l}\text { Behera P, India } \\
\text { medRxiv } \\
\text { doi.org/10.1101/2020.10.29.20222661 }\end{array}$ & $\begin{array}{l}\text { OCT } \\
\mathrm{N}=186 \text { case } \\
\text { control pairs }\end{array}$ & $\begin{array}{l}\text { Health Care } \\
\text { Workers }\end{array}$ & $0.3 \mathrm{mg} / \mathrm{kg}$ & Day 1 and Day 4 & $\begin{array}{l}2 \text { doses reduced odds } \\
\text { of contracting } \\
\text { COVID-19 (OR } 0.27 \\
95 \% \text { CI } 0.16-0.53 \text { ) }\end{array}$ \\
\hline $\begin{array}{l}\text { Bernigaud C. France } \\
\text { Annales de Dermatologie et de } \\
\text { Venereologie } \\
\text { doi.org/10.1016/j.annder.2020.09.231 }\end{array}$ & $\begin{array}{l}\text { OCT } \\
\mathrm{N}=69 \text { case control } \\
\text { pairs }\end{array}$ & $\begin{array}{l}\text { Nursing Home } \\
\text { Residents }\end{array}$ & $0.2 \mathrm{mg} / \mathrm{kg}$ & Once & $\begin{array}{l}10.1 \% \text { vs. } 22.6 \% \\
\text { residents contracted } \\
\text { COVID- } 19 \\
0.0 \% \text { vs } 4.9 \% \\
\text { mortality }\end{array}$ \\
\hline $\begin{array}{l}\text { Hellwig M. USA } \\
\text { J Antimicrobial Agents } \\
\text { doi.org/10.1016/j.ijantimicag.2020.106 } \\
248\end{array}$ & $\begin{array}{l}\text { OCT } \\
\mathrm{N}=52 \text { countries }\end{array}$ & $\begin{array}{l}\text { Countries with } \\
\text { and without } \\
\text { IVM } \\
\text { prophylaxis } \\
\text { programs }\end{array}$ & Unknown & Variable & $\begin{array}{l}\text { Significantly lower- } \\
\text { case incidence of } \\
\text { COVID-19 in African } \\
\text { countries with IVM } \\
\text { prophylaxis programs } \\
\text { p }<.001\end{array}$ \\
\hline Clinical Trials - Outpatients & & & & & $\begin{array}{l}\text { \% Ivermectin vs. } \\
\% \text { Controls }\end{array}$ \\
\hline AUTHOR, COUNTRY, SOURCE & $\begin{array}{l}\text { STUDY DESIGN, } \\
\text { SIZE }\end{array}$ & $\begin{array}{l}\text { STUDY } \\
\text { SUBJECTS }\end{array}$ & $\begin{array}{l}\text { IVERMECTIN } \\
\text { DOSE }\end{array}$ & $\begin{array}{l}\text { DOSE } \\
\text { FREQUENCY }\end{array}$ & $\begin{array}{l}\text { CLINICAL } \\
\text { OUTCOMES } \\
\text { REPORTED }\end{array}$ \\
\hline $\begin{array}{l}\text { Mahmud R, Bangladesh } \\
\text { www.clinicaltrials.gov } \\
\text { NCT0452383 }\end{array}$ & $\begin{array}{l}\text { DB-RCT } \\
\mathrm{N}=363\end{array}$ & $\begin{array}{l}\text { Outpatients and } \\
\text { hospitalized }\end{array}$ & $\begin{array}{l}12 \mathrm{mg}+ \\
\text { doxycycline }\end{array}$ & $\begin{array}{l}\text { Once, within } 3 \\
\text { days of PCR+ } \\
\text { test }\end{array}$ & $\begin{array}{l}\text { Early improvement } \\
60.7 \% \text { vs. } 44.4 \%, \\
\text { p }<.03 \text {, deterioration } \\
8.7 \% \text { vs } 17.8 \%, \mathrm{p}<.02\end{array}$ \\
\hline $\begin{array}{l}\text { Chowdhury A, Bangladesh } \\
\text { Research Square }\end{array}$ & $\begin{array}{l}\text { DB-RCT } \\
\mathrm{N}=116\end{array}$ & Outpatients & $\begin{array}{l}0.2 \mathrm{mg} / / \mathrm{kg}+ \\
\text { doxycycline }\end{array}$ & Once & $\begin{array}{l}\text { Recovery time } 5.9 \text { vs } \\
9.3 \text { days }(p=.07)\end{array}$ \\
\hline
\end{tabular}

This is a provisional file, not the final typeset article 


\section{Efficacy of Ivermectin in COVID-19}

doi.org/10.21203/rs.3.rs-38896/v1

\begin{tabular}{|c|c|c|c|c|c|}
\hline $\begin{array}{l}\text { Ravikirti, India } \\
\text { medRxiv } \\
\text { doi.org/10.1101/2021.01.05.21249310 }\end{array}$ & $\begin{array}{l}\text { DB-RCT } \\
\mathrm{N}=115\end{array}$ & $\begin{array}{l}\text { Mild-moderate } \\
\text { illness }\end{array}$ & $12 \mathrm{mg}$ & Daily for 2 days & $\begin{array}{l}\text { No diff in day } 6 \text { PCR }+ \\
0 \% \text { vs } 6.9 \% \text { mortality, } \\
p=.019\end{array}$ \\
\hline $\begin{array}{l}\text { Babalola OE, Nigeria } \\
\text { medRxiv } \\
\text { doi.org/10.1101/2021.01.05.21249131 }\end{array}$ & $\begin{array}{l}\text { DB-RCT } \\
\mathrm{N}=62\end{array}$ & $\begin{array}{l}\text { Mild-moderate } \\
\text { illness }\end{array}$ & $6 \mathrm{mg}$ and $12 \mathrm{mg}$ & $\begin{array}{l}\text { Every } 48 \mathrm{~h} \text { x } 2 \\
\text { weeks }\end{array}$ & $\begin{array}{l}\text { Time to viral } \\
\text { clearance: } 4.6 \text { days } \\
\text { high dose vs } 6.0 \text { days } \\
\text { low dose vs } 9.1 \text { days } \\
\text { control }(\mathrm{p}=.006)\end{array}$ \\
\hline $\begin{array}{l}\text { Podder CS, Bangladesh } \\
\text { IMC J Med Sci 2020;14(2) }\end{array}$ & $\begin{array}{l}\mathrm{RCT} \\
\mathrm{N}=62\end{array}$ & Outpatients & $0.2 \mathrm{mg} / \mathrm{kg}$ & Once & $\begin{array}{l}\text { Recovery time } 10.1 \text { vs } \\
11.5 \text { days (NS), } \\
\text { average time } 5.3 \text { vs } \\
6.3 \text { (NS) }\end{array}$ \\
\hline $\begin{array}{l}\text { Chaccour C. Spain } \\
\text { Research Square } \\
\text { doi.org/10.21203/rs.3.rs-116547/v1 }\end{array}$ & $\begin{array}{l}\mathrm{RCT} \\
\mathrm{N}=24\end{array}$ & Outpatients & $0.4 \mathrm{mg} / \mathrm{kg}$ & Once & $\begin{array}{l}\text { No diff in PCR }+ \text { Day } \\
7 \text {, lower viral load } \\
\text { days } 4 \text { and } 7,(\mathrm{p}<.05), \\
76 \text { vs } 158 \text { pt. days of } \\
\text { anosmia }(\mathrm{p}<.05), 68 \\
\text { vs } 98 \text { pt. days of } \\
\text { cough }(\mathrm{p}<.05)\end{array}$ \\
\hline $\begin{array}{l}\text { Morgenstern J, Dominican Republic } \\
\text { medRxiv } \\
\text { doi.org/10.1101/2020.10.29.20222505 }\end{array}$ & $\begin{array}{l}\text { Case Series } \\
\mathrm{N}=3,099\end{array}$ & $\begin{array}{l}\text { Outpatients and } \\
\text { hospitalized }\end{array}$ & $\begin{array}{l}\text { Outpatients: } \\
0.4 \mathrm{mg} / \mathrm{kg} \\
\text { Hospital Patients: } \\
0.3 \mathrm{mg} / \mathrm{kg}\end{array}$ & $\begin{array}{l}\text { Outpatients: } 0.3 \mathrm{~m} \\
\mathrm{~g} / \mathrm{kg} \text { x } 1 \text { dose } \\
\text { Inpatients: } \\
0.3 \mathrm{mg} / \mathrm{kg} \text {, Days } \\
1,2,6,7\end{array}$ & $\begin{array}{l}\text { Mortality }=0.03 \% \text { in } \\
2688 \text { outpatients, } 1 \% \\
\text { in } 300 \text { non-ICU } \\
\text { hospital patients, } \\
30.6 \% \text { in } 111 \mathrm{ICU} \\
\text { patients }\end{array}$ \\
\hline $\begin{array}{l}\text { Carvallo H, Argentina } \\
\text { medRxiv } \\
\text { doi.org/10.1101/2020.09.10.20191619 }\end{array}$ & $\begin{array}{l}\text { Case Series } \\
\mathrm{N}=167\end{array}$ & $\begin{array}{l}\text { Outpatients and } \\
\text { hospitalized }\end{array}$ & $\begin{array}{l}24 \mathrm{mg}=\text { mild } \\
36 \mathrm{mg}=\text { moderate } \\
48 \mathrm{mg}=\text { severe }\end{array}$ & Days 0 and 7 & $\begin{array}{l}\text { All } 135 \text { with mild } \\
\text { illness survived, } 1 / 32 \\
\text { ( } 3.1 \% \text { of hospitalized } \\
\text { patients died }\end{array}$ \\
\hline $\begin{array}{l}\text { Alam A, Bangladesh, J of Bangladesh } \\
\text { College Phys and Surg, 2020;38:10-15 } \\
\text { doi.org/10.3329/jbcps.v38i0.47512 }\end{array}$ & $\begin{array}{l}\text { Case series } \\
\mathrm{N}=100\end{array}$ & Outpatients & $\begin{array}{l}0.2 \mathrm{mg} / \mathrm{kg} / \mathrm{kg}+ \\
\text { doxycycline }\end{array}$ & Once & $\begin{array}{l}\text { All improved within } \\
72 \text { hours }\end{array}$ \\
\hline $\begin{array}{l}\text { Espatia-Hernandez G, Mexico } \\
\text { Biomedical Research } \\
\text { www.biomedres.info/biomedi..-proof- } \\
\text { of-concept-study-14435.html }\end{array}$ & $\begin{array}{l}\text { Case Series } \\
\mathrm{N}=28\end{array}$ & Outpatients & $6 \mathrm{mg}$ & Days $1,2,7,8$ & $\begin{array}{l}\text { All pts recovered } \\
\text { Average recovery time } \\
3.6 \text { days }\end{array}$ \\
\hline
\end{tabular}

\begin{tabular}{|c|c|c|c|c|c|}
\hline \multicolumn{5}{|c|}{ Clinical Trials - Hospitalized Patients } & \multirow{2}{*}{$\begin{array}{l}\text { \% Ivermectin vs. } \\
\% \text { Controls } \\
\text { CLINICAL } \\
\text { OUTCOMES } \\
\text { REPORTED }\end{array}$} \\
\hline AUTHOR, COUNTRY, SOURCE & $\begin{array}{l}\text { STUDY DESIGN, } \\
\text { SIZE }\end{array}$ & $\begin{array}{l}\text { STUDY } \\
\text { SUBJECTS }\end{array}$ & $\begin{array}{l}\text { IVERMECTIN } \\
\text { DOSE }\end{array}$ & $\begin{array}{l}\text { DOSE } \\
\text { FREQUENCY }\end{array}$ & \\
\hline $\begin{array}{l}\text { Elgazzar A, Egypt } \\
\text { ResearchSquare } \\
\text { doi.org/10.21203/rs.3.rs-100956/v1 }\end{array}$ & $\begin{array}{l}\text { OL-RCT } \\
\mathrm{N}=400\end{array}$ & $\begin{array}{l}\text { Hospitalized } \\
\text { Patients }\end{array}$ & $0.4 \mathrm{mg} / \mathrm{kg}$ & Once & $\begin{array}{l}\text { Moderately Ill: } \\
\text { worsened } 1 \% \text { vs } 22 \% \text {, } \\
\text { p }<.001 \text {. Severely ill: } \\
\text { worsened } 4 \% \text { vs } 30 \% \\
\text { mortality } 2 \% \text { vs } 20 \% \\
\text { both with } p<.001\end{array}$ \\
\hline $\begin{array}{l}\text { Niaee S. M. } \\
\text { Research Square } \\
\text { doi.org/10.21203/rs.3.rs-109670/v1 }\end{array}$ & $\begin{array}{l}\text { DB-RCT } \\
\mathrm{N}=180\end{array}$ & $\begin{array}{l}\text { Hospitalized } \\
\text { Patients }\end{array}$ & $\begin{array}{l}0.2,0.3,0.4 \mathrm{mg} / \mathrm{kg} \\
(3 \text { dosing strategies })\end{array}$ & $\begin{array}{l}\text { Once vs. Days } \\
1,3,5\end{array}$ & $\begin{array}{l}\text { Mortality } 3.3 \% \text { vs. } \\
18.3 \% \text {. OR } 0.18,(.06- \\
0.55, \mathrm{p}<.05)\end{array}$ \\
\hline $\begin{array}{l}\text { Hashim } \mathrm{H} \text {, Iraq } \\
\text { medRxiv } \\
\text { doi.org/10.1101/2020.10.26.20219345 }\end{array}$ & $\begin{array}{l}\text { SB-RCT } \\
\mathrm{N}=140\end{array}$ & $\begin{array}{l}2 / 3 \text { outpatients, } \\
1 / 3 \text { hospital pts }\end{array}$ & $\begin{array}{l}0.2 \mathrm{mg} / \mathrm{kg}+ \\
\text { doxycycline }\end{array}$ & $\begin{array}{l}\text { Daily for } 2-3 \\
\text { days }\end{array}$ & $\begin{array}{l}\text { Recovery time } 6.3 \text { vs } \\
13.6 \text { days }(p<.001) \text {, } \\
0 \% \text { vs } 27.3 \% \\
\text { mortality in severely } \\
\text { ill }(p=.052)\end{array}$ \\
\hline $\begin{array}{l}\text { Spoorthi S, India } \\
A I A M, 2020 ; 7(10): 177-182\end{array}$ & $\begin{array}{l}\mathrm{RCT} \\
\mathrm{N}=100\end{array}$ & $\begin{array}{l}\text { Hospitalized } \\
\text { Patients }\end{array}$ & $\begin{array}{l}0.2 \mathrm{mg} / \mathrm{kg}+ \\
\text { Doxycycline }\end{array}$ & Once & $\begin{array}{l}\text { Shorter Hospital LOS, } \\
3.7 \text { vs. } 4.7 \text { days, }\end{array}$ \\
\hline
\end{tabular}


Efficacy of Ivermectin in COVID-19

\begin{tabular}{|c|c|c|c|c|c|}
\hline & & & & & $\begin{array}{l}\mathrm{p}=.03, \text { faster } \\
\text { resolution of } \\
\text { symptoms, } 6.7 \text { vs } 7.9 \\
\text { days, } \mathrm{p}=.01\end{array}$ \\
\hline $\begin{array}{l}\text { Ahmed S. Dhaka, Bangladesh } \\
\text { International Journal of Infectious } \\
\text { Disease } \\
\text { doi.org/10.1016/j.ijid.2020.11.191 }\end{array}$ & $\begin{array}{l}\text { DB-RCT } \\
\mathrm{N}=72\end{array}$ & $\begin{array}{l}\text { Hospitalized } \\
\text { Patients }\end{array}$ & $12 \mathrm{mg}$ & Daily for 5 days & $\begin{array}{l}\text { Faster viral clearance } \\
9.7 \text { vs } 12.7 \text { days, } \\
\mathrm{p}=.02\end{array}$ \\
\hline $\begin{array}{l}\text { Chachar AZK, Pakistan } \\
\text { Int J Sciences } \\
\text { doi.org/10.18483/ijSci.2378 }\end{array}$ & $\begin{array}{l}\text { DB-RCT } \\
\mathrm{N}=50\end{array}$ & $\begin{array}{l}\text { Hospitalized } \\
\text { Patients-Mild }\end{array}$ & $12 \mathrm{mg}$ & $\begin{array}{l}\text { Two doses Day } \\
1 \text {, one dose Day } \\
2\end{array}$ & $\begin{array}{l}64 \% \text { vs } 60 \% \\
\text { asymptomatic by Day } \\
7\end{array}$ \\
\hline $\begin{array}{l}\text { Portman-Baracco A, Brazil } \\
\text { Arch Bronconeumol. } 2020 \\
\text { doi.org/10.1016/j.arbres.2020.06.011 }\end{array}$ & $\begin{array}{l}\text { OCT } \\
\mathrm{N}=1408\end{array}$ & $\begin{array}{l}\text { Hospitalized } \\
\text { patients }\end{array}$ & $0.15 \mathrm{mg} / \mathrm{kg}$ & Once & $\begin{array}{l}\text { Overall mortality } \\
1.4 \% \text { vs. } 8.5 \%, \mathrm{HR} \\
0.2,95 \% \text { CI } 0.12-0.37, \\
\text { p }<.0001\end{array}$ \\
\hline $\begin{array}{l}\text { Soto-Beccerra P, Peru } \\
\text { medRxiv } \\
\text { doi.org/10.1101/2020.10.06.20208066 }\end{array}$ & $\begin{array}{l}\text { OCT } \\
\mathrm{N}=5683 \\
\text { IVM, N=563 }\end{array}$ & $\begin{array}{l}\text { Hospitalized } \\
\text { patients, } \\
\text { database } \\
\text { analysis }\end{array}$ & $\begin{array}{l}\text { Unknown dose } \\
<48 \text { hrs after } \\
\text { admission }\end{array}$ & Unknown & No benefits found \\
\hline $\begin{array}{l}\text { Rajter JC, Florida } \\
\text { Chest } 2020 \\
\text { doi.org/10.1016/j.chest.2020.10.009 }\end{array}$ & $\begin{array}{l}\text { OCT } \\
\mathrm{N}=280\end{array}$ & $\begin{array}{l}\text { Hospitalized } \\
\text { patients }\end{array}$ & $\begin{array}{l}0.2 \mathrm{mg} / \mathrm{kg}+ \\
\text { azithromycin }\end{array}$ & $\begin{array}{l}\text { Day } 1 \text { and Day } 7 \\
\text { if needed }\end{array}$ & $\begin{array}{l}\text { Overall mortality } \\
15.0 \% \text { vs. } 25.2 \%, \\
p=.03, \text { Severe illness } \\
\text { mortality } 38.8 \% \text { vs. } \\
80.7 \%, p=.001\end{array}$ \\
\hline $\begin{array}{l}\text { Khan X, Bangladesh } \\
\text { Arch Bronconeumol. } 2020 \\
\text { doi.org/10.1016/j.arbres.2020.08.007 }\end{array}$ & $\begin{array}{l}\text { OCT } \\
\mathrm{N}=248\end{array}$ & $\begin{array}{l}\text { Hospitalized } \\
\text { patients }\end{array}$ & $12 \mathrm{mg}$ & $\begin{array}{l}\text { Once on } \\
\text { admission }\end{array}$ & $\begin{array}{l}\text { Mortality } 0.9 \% \text { vs. } \\
6.8 \%, p<.05, \text { LOS } 9 \\
\text { vs. } 15 \text { days, }<<.001\end{array}$ \\
\hline $\begin{array}{l}\text { Gorial FI, Iraq } \\
\text { medRxiv } \\
\text { doi.org/10.1101/2020.07.07.20145979 }\end{array}$ & $\begin{array}{l}\text { OCT } \\
\mathrm{N}=87\end{array}$ & $\begin{array}{l}\text { Hospitalized } \\
\text { patients }\end{array}$ & $\begin{array}{l}0.2 \mathrm{mg} / \mathrm{kg}+ \\
\mathrm{HCQ} \text { and } \\
\text { azithromycin }\end{array}$ & $\begin{array}{l}\text { Once on } \\
\text { admission }\end{array}$ & $\begin{array}{l}\text { LOS } 7.6 \text { vs. } 13.2 \text { days, } \\
\mathrm{p}<.001,0 / 15 \text { vs. } 2 / 71 \\
\text { died }\end{array}$ \\
\hline $\begin{array}{l}\text { Budiraja S. India } \\
\text { medRxiv } \\
\text { doi.org/10.1101/2020.11.16.20232223 }\end{array}$ & $\begin{array}{l}\text { OCT } \\
\mathrm{N}=1000 \\
\mathrm{IVM}=34\end{array}$ & $\begin{array}{l}\text { Hospitalized } \\
\text { Patients }\end{array}$ & $\mathrm{n} / \mathrm{a}$ & $\mathrm{n} / \mathrm{a}$ & $\begin{array}{l}100 \% \text { IVM pts } \\
\text { recovered } \\
11.1 \% \text { mortality in } \\
\text { non-IVM treated pts }\end{array}$ \\
\hline
\end{tabular}

Legend: DB-RCT = double-blind randomized controlled trial, HCQ $=$ hydroxychloroquine, $\mathrm{IVM}=$ ivermectin, $\mathrm{LOS}=$ Length of stay, NS $=$ nonstatistically significant, $\mathrm{p}>.05, \mathrm{OCT}=$ observational controlled trial, $\mathrm{OL}=$ open label, $\mathrm{PCR}-$ polymerase chain reaction, $\mathrm{RCT}=$ randomized controlled trial, SB-RCT =single blind, randomized controlled trial

\section{Ivermectin in post-COVID-19 syndrome}

Increasing reports of persistent, vexing, and even disabling symptoms after recovery from acute COVID-19 have been reported and which many have termed the condition as "long Covid" and patients as "long haulers", estimated to occur in approximately $10 \%$ of cases (Callard and Perego, 2020;Rubin, 2020;Siegelman, 2020). Generally considered as a post-viral syndrome consisting of a chronic and sometimes disabling constellation of symptoms which include, in order, fatigue, shortness of breath, joint pains and chest pain. Many patients describe their most disabling symptom as impaired memory and concentration, often with extreme fatigue, described as "brain fog", and are highly suggestive of the condition myalgic encephalomyelitis/chronic fatigue syndrome, a condition well-reported to begin after viral infections, in particular with Epstein-Barr virus. Although no specific treatments have been identified for long COVID, a recent manuscript by Aguirre-Chang et al from the National University of San Marcos in Peru reported on the experience with ivermectin in such patients (Aguirre-Chang, 2020). They treated 33 patients who were between 4 and 12 weeks 


\section{Efficacy of Ivermectin in COVID-19}

from the onset of symptoms with escalating doses of ivermectin; $0.2 \mathrm{mg} / \mathrm{kg}$ for 2 days if mild, $0.4 \mathrm{mg} / \mathrm{kg}$ for 2 days if moderate, with doses extended if symptoms persisted. They found that in $87.9 \%$ of the patients, resolution of all symptoms was observed after two doses with an additional $7 \%$ reporting complete resolution after additional doses. Their experience suggests the need for controlled studies to better test efficacy in this vexing syndrome.

\section{Epidemiological data showing impacts of widespread ivermectin use on population case counts and case fatality rates}

Similar to the individual cities in Brazil that measured large decreases in case counts soon after distributing ivermectin in comparison to neighboring cities without such campaigns, in Peru, the government approved the use of ivermectin by decree on May 8, 2020, solely based on the in vitro study by Caly et al. from Australia (Chamie, 2020). ${ }^{8}$ Soon after, multiple state health ministries initiated ivermectin distribution campaigns in an effort to decrease what was at that time some of the highest COVID-19 morbidity and mortality rates in the world. Juan Chamie, a data analyst and member of the FLCCC Alliance recently posted a paper based on two critical sets of data that he compiled and compared; first he identified the timing and magnitude of each region's ivermectin interventions via a review of official communications, press releases, and the Peruvian Situation Room database in order to confirm the dates of effective delivery, and second, he extracted data on the total all-cause deaths from the region along with COVID-19 case counts in selected age groups over time from the registry of the National Computer System of Deaths (SINADEF), and from the National Institute of Statistics and Informatics (Chamie, 2020). It should be noted that he restricted his analyses to only those citizens over 60 years old in order to avoid the confounding of rises in the numbers of infected younger patients. With these data, he was then able to compare the timing of major decreases in this age group of both total COVID-19 cases and total deaths per 1000,000 people among 8 states in Peru with the initiation dates of their respective ivermectin distribution campaigns as shown in Figure 4 below.

$8 \mathrm{https} / /$ trialsitenews.com/trialsite-news-original-documentary-in-peru-about-ivermectin-and-covid-19/ 
Figure 4. Decrease in total case incidences and total deaths/population of COVID-19 in the over 60 population among 8 Peruvian states after deploying mass ivermectin distribution campaigns
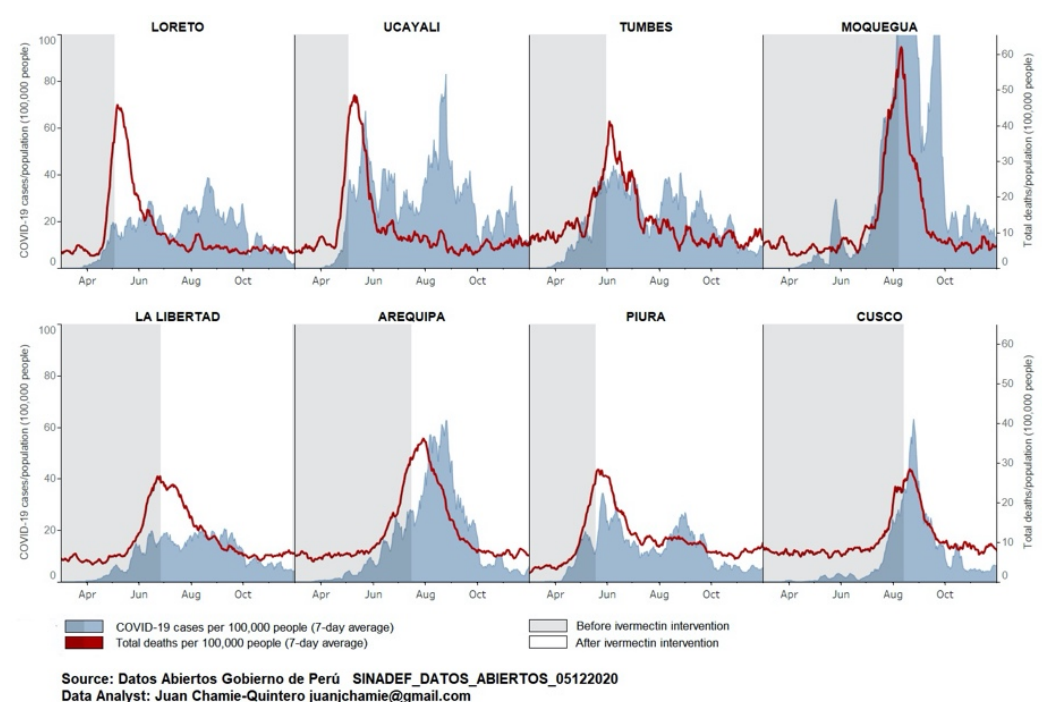

Figure 5 below from the same study presents data on the case fatality rates in patients over 60 , again among the 8 states in Peru. Note the dramatically decreased case fatality rates among older patients with COVID-19 after ivermectin became widely distributed in those areas.

Figure 5. Monthly reported case fatality rates among patients over 60 in eight Peruvian states after deploying mass ivermectin treatment.
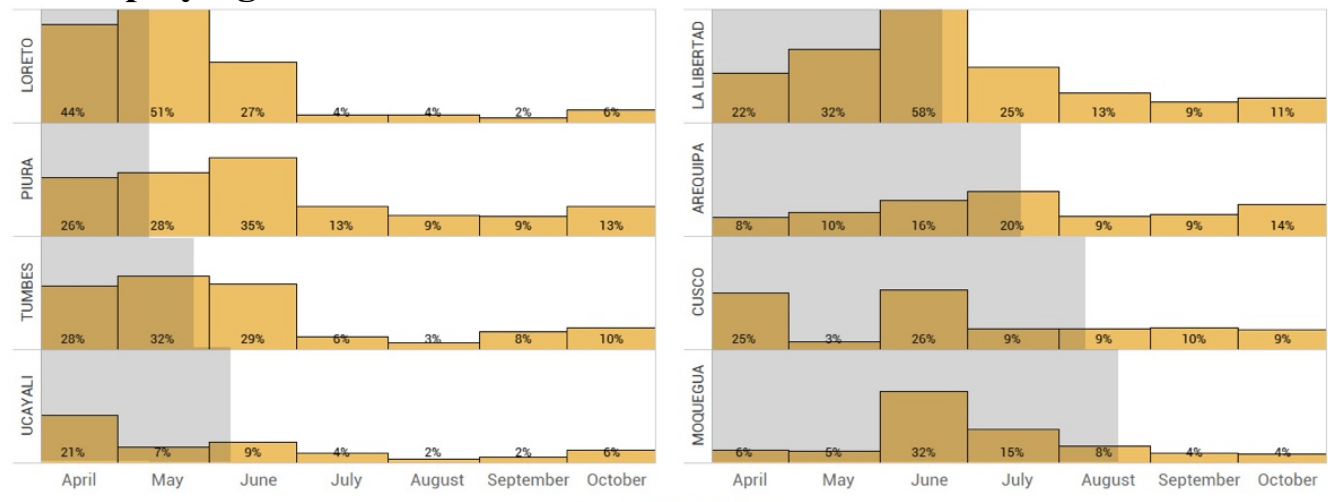

Before IVM intervention
After IVM intervention

Source: Datos Abiertos Gobierno de Perú SINADEF_DATOS_ABIERTOS_08112020 Data Analyst: Juan Chamie @jjchamie

In an even more telling example, Chamie compared the case counts and fatality rates of the 8 states above with the city of Lima, where ivermectin was not distributed nor widely used in treatment during the same time period. Figure 6 below compares the lack of significant or sustained reductions in case counts or fatalities in Lima with the dramatic reductions in both outcomes among the 8 states with widespread ivermectin distribution. 
Figure 6. Covid-19 case fatalities and total deaths with and without mass ivermectin in different states of Peru

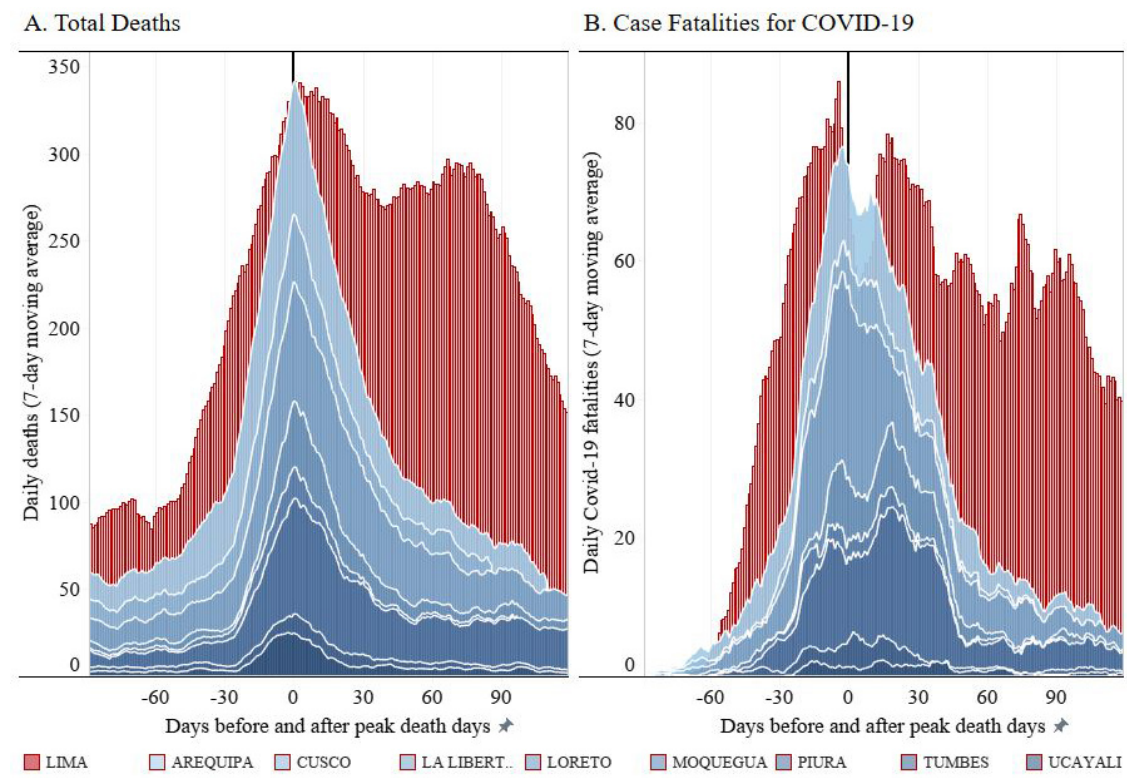

C. Case Incidence for COVID-19

Data Analyst: Juan Chamie juanjchamie@gmail.com

Sources: Total Deaths: cloud.minsa.gob.pe/s/NctBnHXDnocgWAg/download; datosabiertos.gob.pe/group/datos-abiertos-de-covid-19

Legend: Daily total deaths, case fatalities and case incidence for COVID-19 in populations of patients age 60 and above for eight states in Peru deploying early mass ivermectin treatments vs. the state of Lima, including the capital city, where ivermectin treatment was applied months later.

Another compelling example can be seen from the data compiled from Paraguay, again by Chamie, who noted that the government of the state of Alto Parana had launched an ivermectin distribution campaign in early September. Although the campaign was officially described as a "deworming" program, this was interpreted as a guise by the regions' governor to avoid reprimand or conflict with the National Ministry of Health that recommended against use of ivermectin to treat COVID-19 in Paraguay. ${ }^{9}$ The program began with a distribution of 30,000 boxes of ivermectin and by October 15, the governor declared that there were very few cases left in the state as can be seen in Figure 7 below. ${ }^{10}$

\footnotetext{
9 https://public.tableau.com/profile/jchamie\#!/vizhome/COVID-19PARAGUAY/Paraguay

10 https://public.tableau.com/profile/jchamie\#!/vizhome/COVID-19PARAGUAY/Paraguay
} 
Figure 7. Paraguay - COVID-19 case counts and deaths in Alto Parana (bolded blue line) after ivermectin distribution began compared to other regions.

COVID-19 IN PARAGUAY

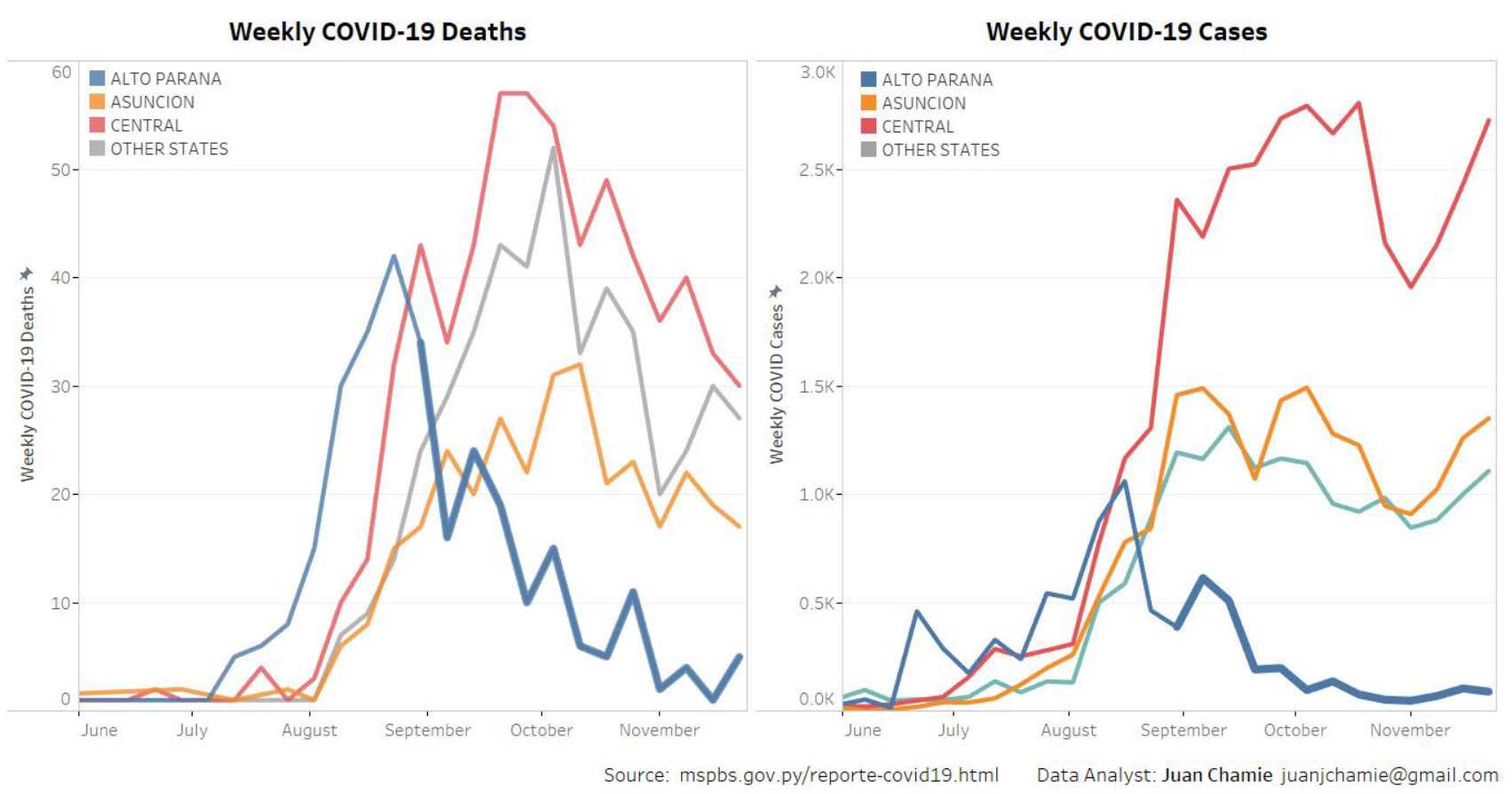

\section{The clinical evidence base for ivermectin against COVID-19}

A summary of the statistically significant results from the above controlled trials are as follows:

\section{Controlled trials in the prophylaxis of COVID-19 (8 studies)}

- All 8 available controlled trial results show statistically significant reductions in transmission

- 3 RCT's with large statistically significant reductions in transmission rates, $\mathrm{N}=774$ patients (Chala, 2020;Elgazzar et al., 2020;Shouman, 2020)

- 5 OCT's with large statistically significant reductions in transmission rates, $\mathrm{N}=2052$ patients (Alam et al., 2020;Behera et al., 2020;Bernigaud et al., 2020;Carvallo et al., 2020b;Hellwig and Maia, 2020)

\section{Controlled trials in the treatment of COVID-19 (19 studies)}

- 5 RCT's with statistically significant impacts in time to recovery or hospital length of stay (Elgazzar et al., 2020; Hashim et al., 2020;Mahmud, 2020;Niaee et al., 2020; Spoorthi V, 2020)

- 1 RCT with a near statistically significant decrease in time to recovery, $p=.07, N=130$ (Chowdhury et al., 2020)

- 1 RCT with a large, statistically significant reduction in the rate of deterioration or hospitalization, $\mathrm{N}=363$ (Mahmud, 2020)

- 2 RCT's with a statistically significant decrease in viral load, days of anosmia and cough, $\mathrm{N}=85$ (Chaccour et al., 2020; Ravikirti et al., 2021) 


\section{Efficacy of Ivermectin in COVID-19}

- 3 RCT's with large, statistically significant reductions in mortality $(\mathrm{N}=695)$ (Elgazzar et al., 2020; Niaee et al., 2020; Ravikirti et al., 2021)

- 1 RCT with a near statistically significant reduction in mortality, $\mathrm{p}=0.052(\mathrm{~N}=140)$ (Hashim et al., 2020)

- 3 OCT's with large, statistically significant reductions in mortality $(\mathrm{N}=1,688)$ (Khan et al., 2020;Portmann-Baracco et al., 2020;Rajter et al., 2020)

\section{Safety of Ivermectin}

Numerous studies report low rates of adverse events, with the majority mild, transient, and largely attributed to the body's inflammatory response to the death of the parasites and include itching, rash, swollen lymph nodes, joint paints, fever and headache (Kircik et al., 2016). In a study which combined results from trials including over 50,000 patients, serious events occurred in less than $1 \%$ and largely associated with administration in Loa loa (Gardon et al., 1997). Further, according to the pharmaceutical reference standard Lexicomp, the only medications contraindicated for use with ivermectin are the concurrent administration of anti-tuberculosis and cholera vaccines while the anticoagulant warfarin would require dose monitoring. Another special caution is that immunosuppressed or organ transplant patients who are on calcineurin inhibitors such as tacrolimus or cyclosporine or the immunosuppressant sirolimus should have close monitoring of drug levels when on ivermectin given that interactions exist which can affect these levels. A longer list of drug interactions can be found on the drugs.com database, with nearly all interactions leading to a possibility of either increased or decreased blood levels of ivermectin. Given studies showing tolerance and lack of adverse effects in human subjects given escalating high doses of ivermectin, toxicity is unlikely although a reduced efficacy due to decreased levels may be a concern (Guzzo et al., 2002)..

Concerns of safety in the setting of liver disease are unfounded given that, to our knowledge, only two cases of liver injury have ever been reported in association with ivermectin, with both cases rapidly resolved without need for treatment. (Sparsa et al., 2006; Veit et al., 2006). Further, no dose adjustments are required in patients with liver disease. Some have described ivermectin as potentially neurotoxic, yet one study performed a search of a global pharmaceutical database and found only 28 cases of serious neurological adverse events such as ataxia, altered consciousness, seizure, or tremor (Chandler, 2018). Potential explanations included the effects of concomitantly administered drugs which increase absorption past the blood brain barrier or polymorphisms in the mdr-1 gene. However, the total number of reported cases suggests that such events are rare. Finally, ivermectin has been used safely in pregnant women, children, and infants.

\section{Discussion}

Currently, as of December 14,2020, the accumulating evidence demonstrating the safety and efficacy of ivermectin in COVID-19 strongly supports its immediate use on a risk/benefit calculation in the context of a pandemic. Large-scale epidemiologic analyses validate the findings of in vitro, animal, prophylaxis, and clinical studies. Regions of the world with widespread ivermectin use have demonstrated a sizable reduction in case counts, hospitalizations, and fatality rates. This approach should be urgently considered in the presence of an escalating COVID-19 pandemic and as a bridge to vaccination. A recent systematic review of eight RCTs by Australian researchers, published as a pre-print, similarly concluded that ivermectin treatment led to a reduction in mortality, time to clinical recovery, the incidence of disease progression, and duration of hospital admission in patients across all stages of clinical severity (Kalfas et al., 2020). Our current review includes a total of 6,612 


\section{Efficacy of Ivermectin in COVID-19}

patients from 27 controlled studies [16 of them were RCTs, 5 double blinded, one single blinded, $(\mathrm{n}=$ 2,503)]; 11 published in peer-reviewed journals including 3,900 patients.

Pre-print publications have exploded during the COVID-19 pandemic. Except for hydroxychloroquine and convalescent plasma that were widely adopted before availability of any clinical data to support, almost all subsequent therapeutics were adopted after pre-print publication and prior to peer review. Examples include remdesivir, corticosteroids, and monoclonal antibodies. An even more aggressive example of rapid adoption was the initiation of inoculation programs using novel mRNA vaccines prior to review of either pre-print or peer-reviewed trials data by physicians ordering the inoculations for patients. ${ }^{11}$ In all such situations, both academia and governmental health care agencies relaxed their standard to rise to the needs dictated by the pandemic.

In the context of ivermectin's long standing safety record, low cost, and wide availability along with the consistent, reproducible, large magnitude findings on transmission rates, need for hospitalization, mortality, and population-wide control of COVID-19 case and fatality rates in areas with widespread ivermectin distribution, insisting on the remaining studies to pass peer review prior to widespread adoption appears to be imprudent and to deviate from the now established standard approach towards adoption of new therapeutics during the pandemic. In fact, insisting on such a barrier to adoption would actually violate this new standard given that 12 of the 24 controlled trials have already been published in peer reviewed journals.

In regard to concerns over the validity of observational trial findings, it must be recognized that in the case of ivermectin; 1) half of the trials employed a randomized, controlled trial design (12 of the 24 reviewed above), and 2) that observational and randomized trial designs reach equivalent conclusions on average in nearly all diseases studied, as reported in a large Cochrane review of the topic from 2014 (Anglemyer et al., 2014). In particular, OCTs that employ propensity-matching techniques (as in the Rijter study from Florida), find near identical conclusions to later-conducted RCTs in many different disease states, including coronary syndromes, critical illness, and surgery (Dahabreh et al., 2012;Lonjon et al., 2014;Kitsios et al., 2015). Similarly, as evidenced in the prophylaxis (Figure 1) and treatment trial (Figures 2 and 3) meta-analyses as well as the summary trials table (Table 3), the entirety of the benefits found in both OCT and RCT trial designs align in both direction and magnitude of benefit. Such a consistency of benefit amongst numerous trials of varying designs from multiple different countries and centers around the world is both unique in the history of evidence-based medicine and provides strong, additional support to the conclusions reached in this review. All must consider Declaration 37 of the World Medical Association's "Helsinki Declaration on the Ethical Principles for Medical Research Involving Human Subjects," first established in 1964, which states:

In the treatment of an individual patient, where proven interventions do not exist or other known interventions have been ineffective, the physician, after seeking expert advice, with informed consent from the patient or a legally authorized representative, may use an unproven intervention if in the physician's judgement it offers hope of saving life, reestablishing health or alleviating suffering. This intervention should subsequently be made the object of research, designed to evaluate its safety and efficacy. In all cases, new information must be recorded and, where appropriate, made publicly available.

The continued challenges faced by health care providers in deciding on appropriate therapeutic interventions in patients with COVID-19 would be greatly eased if more updated and definitive evidence-based guidance came from the leading governmental health care agencies. Currently, in the United States, the treatment guidelines for COVID-19 are issued by the National

11 https:/www.wsj.com/articles/u-k-begins-rollout-of-pfizers-covid-19-vaccine-in-a-first-for-the-west-11607419672 


\section{Efficacy of Ivermectin in COVID-19}

Institutes of Health (NIH). Unfortunately, the NIH's recommendation on the use of ivermectin in COVID-19 patients was last updated on August 27, 2020. At that time, ivermectin received a recommendation of A-III against use outside of a clinical trial. An A-III recommendation, per the NIH recommendation scheme, means that it was a strong opinion (A), and based on expert opinion only (III) given that presumably little clinical evidence existed at the time to otherwise inform that recommendation.

Based on the totality of the clinical and epidemiologic evidence presented in this review, and in the context of a worsening pandemic in parts of the globe where ivermectin is not widely used, the authors believe the recommendation must be immediately updated to support and guide the nation's health care providers. One aspect that the NIH expert panel may debate is on the grade of recommendation that should be assigned to ivermectin. Based on the NIH rating scheme, the strongest recommendation possible would be an A-I in support of ivermectin which requires "one or more randomized trials with clinical outcomes and/or laboratory endpoints." Given that data from 16 randomized controlled trials (RCT's) demonstrate consistent and large improvements in "clinical outcomes" such as transmission rates, hospitalization rates, and death rates, it appears that the criteria for an A-I level recommendation has been exceeded. However, although troubling to consider, if experts somehow conclude that the entirety of the available RCT data should be invalidated and dismissed given that either; they were conducted outside of US shores and not by US pharmaceutical companies or academic research centers, that some studies were small or of "low quality", or that such data from foreign countries are not generalizable to American patients, an A-II level recommendation would then have to be considered. In the context of worsening pandemic conditions, when considering a safe, low-cost, widely available early treatment option, even an A-II would result in immediate, widespread adoption by providers in the treatment of COVID-19. The criteria for an A-II requires supportive findings from "one of more well-designed non-randomized, or observational cohort studies". Fortunately, there are many such studies on ivermectin in COVID-19, with one of the largest and best designed being Dr. Rijter's study from Florida, published in the major peerreviewed medical journal Chest, where they used propensity matching, a technique accorded by many to be as valid a design as RCT's. Thus, at a minimum, an A-II recommendation is met, which again would and should lead to immediate and widespread adoption in early outpatient treatment, an area that has been little investigated and is devoid of any highly effective therapies at the time of this writing. Further, it is clear that these data presented far exceed any other NIH strength or quality level such as moderate strength (B), weak strength (C) or grade III quality. To merit the issuance of these lower grades of recommendation would require both a dismissal of the near entirety of the evidence presented in this review in addition to a risk benefit calculation resulting in the belief that the risks of widespread ivermectin use would far exceed any possible benefits in the context of rising case counts, deaths, lockdowns, unemployment, evictions, and bankruptcies.

It is the authors opinion, that based on the totality of these data, the use of ivermectin as a prophylactic and early treatment option should receive an A-I level recommendation by the NIH in support of use by the nation's health care providers. When, or if, such a recommendation is issued, the Front Line COVID-19 Critical Care Alliance has developed a prophylaxis and early treatment protocol for COVID-19 (I-MASK+), centered around ivermectin combined with masking, social distancing, hand hygiene, Vitamin D, Vitamin C, quercetin, melatonin, and zinc, with all components known for either their anti-viral, anti-inflammatory, or preventive actions (Table 4). The I-MASK+ protocol suggests treatment approaches for prophylaxis of high-risk patients, post-exposure prophylaxis of household members with COVID-19, and an early treatment approach for patients ill with COVID-19. 
Table 4. I-MASK+ Prophylaxis \& Early Outpatient Treatment Protocol for COVID-19

\begin{tabular}{ll}
\hline Prophylaxis Protocol \\
\hline MEDICATION & RECOMMENDED DOSING \\
\hline lvermectin & $\begin{array}{l}\text { Prophylaxis for high-risk individuals: } \\
0.2 \mathrm{mg} / \mathrm{kg} \text { per dose } * \text { one dose today, } 2^{\text {nd }} \text { dose in } 48 \text { hours, then one dose every } 2 \text { weeks }\end{array}$ \\
\hline Post COVID-19 exposure prophylaxis $* * * 0.2 \mathrm{mg} / \mathrm{kg}$ per dose, one dose today, $2^{\text {nd }}$ dose in 48 hours \\
\hline Vitamin D3 & $1,000-3,000$ IU/day \\
\hline Vitamin C & $1,000 \mathrm{mg}$ twice daily \\
\hline Quercetin & $250 \mathrm{mg} /$ day \\
\hline Melatonin & $6 \mathrm{mg}$ before bedtime (causes drowsiness) \\
\hline Zinc & $50 \mathrm{mg} /$ day of elemental zinc \\
\hline Early Outpatient Treatment Protocol**** \\
\hline MEDICATION & RECOMMENDED DOSING \\
\hline lvermectin & $0.2 \mathrm{mg} / \mathrm{kg}$ per dose - one dose daily for minimum of 2 days, continue daily until recovered (max 5 days) \\
\hline Vitamin D3 & $4,000 \mathrm{IU} /$ day \\
\hline Vitamin C & $2,000 \mathrm{mg} 2-3$ times daily and Quercetin $250 \mathrm{mg}$ twice a day \\
\hline Melatonin & $10 \mathrm{mg}$ before bedtime (causes drowsiness) \\
\hline Zinc & $100 \mathrm{mg} /$ day elemental zinc \\
\hline Aspirin & $325 \mathrm{mg} /$ day (unless contraindicated) \\
\hline
\end{tabular}

* Example for a person of $60 \mathrm{~kg}$ body weight: $60 \mathrm{~kg} \times 0.2 \mathrm{mg}=12 \mathrm{mg}(1 \mathrm{~kg}=2.2 \mathrm{lbs})=4$ tablets (3mg/tablet). To convert pounds, divide weight in pounds by 11: example for a person of 165 pounds: $165 \div 11=15 \mathrm{mg}$

** The dosing may be updated as further scientific studies emerge.

*** To use if a household member is COVID-19 positive, or if you have had prolonged exposure to a COVID-19+ patient without wearing a mask

**** For late phase - hospitalized patients - see the FLCCC's "MATH+" protocol on www.flccc.net

In summary, based on the existing and cumulative body of evidence, we recommend the use of ivermectin in both prophylaxis and treatment for COVID-19. In the presence of a global COVID19 surge, the widespread use of this safe, inexpensive, and effective intervention would lead to a drastic reduction in transmission rates and the morbidity and mortality in mild, moderate, and even severe disease phases. The authors are encouraged and hopeful at the prospect of the many favorable public health and societal impacts that would result once adopted for use.

\section{Acknowledgements}

None

\section{Contribution to the field statement}




\section{Efficacy of Ivermectin in COVID-19}

COVID-19 has caused a worldwide pandemic that has caused over 1.5 million global deaths along with continued rising case counts, lockdowns, unemployment and recessions in multiple countries. In response, the Front Line COVID-19 Critical Care Alliance (FLCCC), formed early in the pandemic, began to review the rapidly emerging basic science, translational, and clinical data to develop effective treatment protocols. The supportive evidence and rationale for their highly effective hospital treatment protocol called "MATH+" was recently published in a major medical journal. More recently, during their ongoing review of the studies on a wide range of both novel and repurposed drugs, they identified that ivermectin, a widely used anti-parasitic medicine with known anti-viral and anti-inflammatory properties is proving a highly potent and multi-phase effective treatment against COVID-19. This manuscript comprehensively reviews the diverse and increasing amount of available evidence from studies on ivermectin which then concludes with the FLCCC consensus recommendation that ivermectin for both the prophylaxis and treatment of COVID-19 should be systematically and globally adopted with the achievable goal of saving countless lives and reversing the rising and persistent transmission rates in many areas of the world.

\section{Figures}

\section{Conflict of Interest}

The authors declare that the research was conducted in the absence of any commercial or financial relationships that could be construed as a potential conflict of interest.

\section{Author Contributions}

Study conception and design: Pierre Kory, G. Umberto Meduri, Howard Kornfeld, Keith Berkowitz. Acquisition of data: Scott Mitchell, Eivind Norjevoll, Paul Marik, Fred Wagshul Analysis and interpretation of data: Paul Marik, Pierre Kory Drafting of manuscript: Pierre Kory Critical revision: Umberto Meduri, Joseph Varon.

\section{Funding}

There was no funding involved for this project.

\section{Acknowledgments}

None.

\section{References}




\section{Efficacy of Ivermectin in COVID-19}

$<$ WHO-2019-nCoV-Corticosteroids-2020.1-eng.pdf $>$.

Agarwal, A., Mukherjee, A., Kumar, G., Chatterjee, P., Bhatnagar, T., Malhotra, P., and Collaborators, P.T. (2020). Convalescent plasma in the management of moderate covid-19 in adults in India: open label phase II multicentre randomised controlled trial (PLACID Trial). BMJ 371, m3939.

Aguirre-Chang, G. (2020). Post-Acute or prolonged COVID-19: treatment with ivermectin for patietns with persistent, or post-acute symptoms ResearchGate.

Ahmed, S., Karim, M.M., Ross, A.G., Hossain, M.S., Clemens, J.D., Sumiya, M.K., Phru, C.S., Rahman, M., Zaman, K., and Somani, J. (2020). A five day course of ivermectin for the treatment of COVID-19 may reduce the duration of illness. International Journal of Infectious Diseases.

Alam, M., R, M., Pf, G., Md, M.Z., S, S., and Ma, C. (2020). Ivermectin as Pre-exposure Prophylaxis for COVID 19

among Healthcare Providers in a Selected Tertiary

Hospital in Dhaka An Observational Study. European Journal of Medical and Health Sciences.

Anglemyer, A., Horvath, H.T., and Bero, L. (2014). Healthcare outcomes assessed with observational study designs compared with those assessed in randomized trials. Cochrane Database Syst Rev, MR000034.

Arevalo, A.P., Pagotto, R., Porfido, J., Daghero, H., Segovia, M., Yamasaki, K., Varela, B., Hill, M., Verdes, J.M., and Vega, M.D. (2020). Ivermectin reduces coronavirus infection in vivo: a mouse experimental model. bioRxiv.

Atkinson, S.C., Audsley, M.D., Lieu, K.G., Marsh, G.A., Thomas, D.R., Heaton, S.M., Paxman, J.J., Wagstaff, K.M., Buckle, A.M., Moseley, G.W., Jans, D.A., and Borg, N.A. (2018). Recognition by host nuclear transport proteins drives disorder-to-order transition in Hendra virus V. Scientific Reports 8, 358.

Babalola, O.E., Bode, C.O., Ajayi, A.A., Alakaloko, F.M., Akase, I.E., Otrofanowei, E., Salu, O.B., Adeyemo, W.L., Ademuyiwa, A.O., and Omilabu, S.A. Ivermectin shows clinical benefits in mild to moderate Covid19 disease: A randomised controlled double blind dose response study in Lagos. medRxiv, 2021.2001. 2005.21249131.

Behera, P., Patro, B.K., Singh, A.K., Chandanshive, P.D., Ravikumar, S., Pradhan, S.K., Pentapati, S.S.K., Batmanabane, G., Padhy, B.M., and Bal, S. (2020). Role of ivermectin in the prevention of COVID-19 infection among healthcare workers in India: A matched casecontrol study. medRxiv.

Bernigaud, C., Guillemot, D., Ahmed-Belkacem, A., Grimaldi-Bensouda, L., Lespine, A., Berry, F., Softic, L., Chenost, C., Do-Pham, G., and Giraudeau, B. (Year). "Bénéfice de l'ivermectine: de la gale à la COVID-19, un exemple de sérendipité", in: Annales de Dermatologie et de Vénéréologie: Elsevier), A194.

Bray, M., Rayner, C., Noël, F., Jans, D., and Wagstaff, K. (2020). Ivermectin and COVID-19: a report in Antiviral Research, widespread interest, an FDA warning, two letters to the editor and the authors' responses. Antiviral Research.

Budhiraja, S., Soni, A., Jha, V., Indrayan, A., Dewan, A., Singh, O., Singh, Y., Chugh, I., Arora, V., and Pandey, R. (2020). Clinical Profile of First 1000 COVID-19 Cases Admitted at Tertiary Care Hospitals and the Correlates of their Mortality: An Indian Experience. medRxiv.

Cadegiani, F.A., Goren, A., Wambier, C.G., and Mccoy, J. (2020). Early COVID-19 Therapy with Azithromycin Plus Nitazoxanide, Ivermectin or Hydroxychloroquine in Outpatient Settings Significantly Reduced Symptoms Compared to Known Outcomes in Untreated Patients. medRxiv.

Callard, F., and Perego, E. (2020). How and why patients made Long Covid. Social Science \& Medicine, 113426. 


\section{Efficacy of Ivermectin in COVID-19}

Caly, L., Druce, J.D., Catton, M.G., Jans, D.A., and Wagstaff, K.M. (2020a). The FDA-approved drug ivermectin inhibits the replication of SARS-CoV-2 in vitro. Antiviral Res 178, 104787.

Caly, L., Druce, J.D., Catton, M.G., Jans, D.A., and Wagstaff, K.M. (2020b). The FDA-approved drug ivermectin inhibits the replication of SARS-CoV-2 in vitro. Antiviral Research 178, 104787.

Carvallo, H.E., Hirsch, R.R., and Farinella, M.E. (2020a). Safety and Efficacy of the combined use of ivermectin, dexamethasone, enoxaparin and aspirin against COVID-19. medRxiv.

Carvallo, H.E., Roberto, H., Psaltis, A., and Veronica, C. (2020b). Study of the Efficacy and Safety of Topical Ivermectin+ Iota-Carrageenan in the Prophylaxis against COVID-19 in Health Personnel.

Chaccour, C., Casellas, A., Blanco-Di Matteo, A., Pineda, I., Fernandez-Montero, A., Castillo, P.R., Richardson, M.-A., Mateos, M.R., Jordan-Iborra, C., and Brew, J. (2020). The effect of early treatment with ivermectin on viral load, symptoms and humoral response in patients with mild COVID-19: a pilot, double-blind, placebo-controlled, randomized clinical trial.

Chachar, A.Z.K., Khan, K.A., Asif, M., Tanveer, K., Khaqan, A., and Basri, R. (2020). Effectiveness of Ivermectin in SARS-CoV-2/COVID-19 Patients. International Journal of Sciences 9, 3135.

Chala (2020). Prophylaxis Covid-19 in Healthcare Agents by Intensive Treatment With Ivermectin and Iota-carrageenan (Ivercar-Tuc). ClinicalTrials.gov NCT04701710.

Chamie, J. (2020). Real-World Evidence: The Case of Peru. Causality between Ivermectin and COVID-19 Infection Fatality Rate.

Chandler, R.E. (2018). Serious neurological adverse events after ivermectin-do they occur beyond the indication of onchocerciasis? The American journal of tropical medicine and hygiene 98, 382-388.

Chowdhury, A.T.M.M., Shahbaz, M., Karim, M.R., Islam, J., Guo, D., and He, S. (2020). A Randomized Trial of Ivermectin-Doxycycline and Hydroxychloroquine-Azithromycin therapy on COVID19 patients.

Ci, X., Li, H., Yu, Q., Zhang, X., Yu, L., Chen, N., Song, Y., and Deng, X. (2009). Avermectin exerts anti-inflammatory effect by downregulating the nuclear transcription factor kappa-B and mitogen-activated protein kinase activation pathway. Fundam Clin Pharmacol 23, 449455.

Consortium, W.S.T. (2020). Repurposed antiviral drugs for COVID-19-interim WHO SOLIDARITY trial results. medRxiv. Preprint posted online 15.

Crump, A., and Omura, S. (2011). Ivermectin, 'wonder drug'from Japan: the human use perspective. Proceedings of the Japan Academy, Series B 87, 13-28.

Dahabreh, I.J., Sheldrick, R.C., Paulus, J.K., Chung, M., Varvarigou, V., Jafri, H., Rassen, J.A., Trikalinos, T.A., and Kitsios, G.D. (2012). Do observational studies using propensity score methods agree with randomized trials? A systematic comparison of studies on acute coronary syndromes. European Heart Journal 33, 1893-1901.

Dasgupta J, S.U., Bakshi a, Dasgupta a, Manna K, Saha, C De, Rk, Mukhopadhyay S, Bhattacharyya Np (2020). Nsp7 and Spike Glycoprotein of SARS-CoV-2 Are Envisaged as Potential Targets of Vitamin D and Ivermectin. Preprints.

Dayer, M.R. (2020). Coronavirus (2019-nCoV) Deactivation via Spike Glycoprotein Shielding by Old Drugs, Bioinformatic Study.

De Melo, G.D., Lazarini, F., Larrous, F., Feige, L., Kergoat, L., Marchio, A., Pineau, P., Lecuit, M., Lledo, P.-M., Changeux, J.-P., and Bourhy, H. (2020). Anti-COVID-19 efficacy of ivermectin in the golden hamster. bioRxiv, 2020.2011.2021.392639.

Elgazzar, A., Hany, B., Youssef, S.A., Hafez, M., and Moussa, H. (2020). Efficacy and Safety of Ivermectin for Treatment and prophylaxis of COVID-19 Pandemic. 


\section{Efficacy of Ivermectin in COVID-19}

Entrenas Castillo, M., Entrenas Costa, L.M., Vaquero Barrios, J.M., Alcala Diaz, J.F., Lopez Miranda, J., Bouillon, R., and Quesada Gomez, J.M. (2020). "Effect of calcifediol treatment and best available therapy versus best available therapy on intensive care unit admission and mortality among patients hospitalized for COVID-19: A pilot randomized clinical study". $J$ Steroid Biochem Mol Biol 203, 105751.

Espitia-Hernandez, G., Munguia, L., Diaz-Chiguer, D., Lopez-Elizalde, R., and Jimenez-Ponce, F. (2020). Effects of Ivermectin-azithromycin-cholecalciferol combined therapy on COVID-19 infected patients: a proof of concept study.

Gardon, J., Gardon-Wendel, N., Demanga, N., Kamgno, J., Chippaux, J.-P., and Boussinesq, M. (1997). Serious reactions after mass treatment of onchocerciasis with ivermectin in an area endemic for Loa loa infection. The Lancet 350, 18-22.

Gorial, F.I., Mashhadani, S., Sayaly, H.M., Dakhil, B.D., Almashhadani, M.M., Aljabory, A.M., Abbas, Hassan M, Ghanim, M., and Rasheed, J.I. (2020). Effectiveness of Ivermectin as addon Therapy in COVID-19 Management (Pilot Trial). medRxiv.

Götz, V., Magar, L., Dornfeld, D., Giese, S., Pohlmann, A., Höper, D., Kong, B.-W., Jans, D.A., Beer, M., Haller, O., and Schwemmle, M. (2016). Influenza A viruses escape from MxA restriction at the expense of efficient nuclear vRNP import. Scientific Reports 6, 23138.

Guzzo, C., Furtek, C., Porras, A., Chen, C., Tipping, R., Clineschmidt, C., Sciberras, D., Hsieh, J., and Lasseter, K. (2002). Safety, Tolerability, and Pharmacokinetics of Escalating High Doses of Ivermectin in Healthy Adult Subjects. Journal of clinical pharmacology 42, 1122-1133.

Hashim, H.A., Maulood, M.F., Rasheed, A.M., Fatak, D.F., Kabah, K.K., and Abdulamir, A.S. (2020). Controlled randomized clinical trial on using Ivermectin with Doxycycline for treating COVID-19 patients in Baghdad, Iraq. medRxiv.

Hellwig, M.D., and Maia, A. (2020). A COVID-19 Prophylaxis? Lower incidence associated with prophylactic administration of Ivermectin. Int J Antimicrob Agents, 106248.

Hermine, O., Mariette, X., Tharaux, P.L., Resche-Rigon, M., Porcher, R., Ravaud, P., and Group, C.C. (2020). Effect of Tocilizumab vs Usual Care in Adults Hospitalized With COVID-19 and Moderate or Severe Pneumonia: A Randomized Clinical Trial. JAMA Intern Med.

Horby, P., Lim, W.S., Emberson, J.R., Mafham, M., Bell, J.L., Linsell, L., Staplin, N., Brightling, C., Ustianowski, A., and Elmahi, E. (2020). Dexamethasone in hospitalized patients with Covid19-preliminary report. The New England journal of medicine.

Hussien, M.A., and Abdelaziz, A.E. (2020). Molecular docking suggests repurposing of brincidofovir as a potential drug targeting SARS-CoV-2 ACE2 receptor and main protease. Network Modeling Analysis in Health Informatics and Bioinformatics 9, 1-18.

Jehi, L., Ji, X., Milinovich, A., Erzurum, S., Rubin, B.P., Gordon, S., Young, J.B., and Kattan, M.W. (2020). Individualizing Risk Prediction for Positive Coronavirus Disease 2019 Testing: Results From 11,672 Patients. Chest 158, 1364-1375.

Kalfas, S., Visvanathan, K., Chan, K., and Drago, J. (2020). THE THERAPEUTIC POTENTIAL OF IVERMECTIN FOR COVID-19: A REVIEW OF MECHANISMS AND EVIDENCE. medRxiv.

Khan, M.S.I., Khan, M.S.I., Debnath, C.R., Nath, P.N., Mahtab, M.A., Nabeka, H., Matsuda, S., and Akbar, S.M.F. (2020). Ivermectin Treatment May Improve the Prognosis of Patients With COVID-19. Archivos de Bronconeumología.

King, C.R., Tessier, T.M., Dodge, M.J., Weinberg, J.B., and Mymryk, J.S. (2020). Inhibition of Human Adenovirus Replication by the Importin $\alpha / \beta 1$ Nuclear Import Inhibitor Ivermectin. Journal of Virology 94.

Kircik, L.H., Del Rosso, J.Q., Layton, A.M., and Schauber, J. (2016). Over 25 Years of Clinical Experience With Ivermectin: An Overview of Safety for an Increasing Number of Indications. Journal of drugs in dermatology : JDD 15, 325-332. 


\section{Efficacy of Ivermectin in COVID-19}

Kitsios, G.D., Dahabreh, I.J., Callahan, S., Paulus, J.K., Campagna, A.C., and Dargin, J.M. (2015). Can We Trust Observational Studies Using Propensity Scores in the Critical Care Literature? A Systematic Comparison With Randomized Clinical Trials. Crit Care Med 43, 1870-1879.

Kory, P., Meduri, G.U., Iglesias, J., Varon, J., and Marik, P.E. (2020). Clinical and Scientific Rationale for the "MATH+" Hospital Treatment Protocol for COVID-19. Journal of Intensive Care Medicine.

Lehrer, S., and Rheinstein, P.H. (2020). Ivermectin Docks to the SARS-CoV-2 Spike Receptorbinding Domain Attached to ACE2. In Vivo 34, 3023-3026.

Li, Y., Chen, M., Cao, H., Zhu, Y., Zheng, J., and Zhou, H. (2013). Extraordinary GU-rich singlestrand RNA identified from SARS coronavirus contributes an excessive innate immune response. Microbes Infect 15, 88-95.

Lonjon, G., Boutron, I., Trinquart, L., Ahmad, N., Aim, F., Nizard, R., and Ravaud, P. (2014). Comparison of treatment effect estimates from prospective nonrandomized studies with propensity score analysis and randomized controlled trials of surgical procedures. Ann Surg 259, 18-25.

Lv, C., Liu, W., Wang, B., Dang, R., Qiu, L., Ren, J., Yan, C., Yang, Z., and Wang, X. (2018). Ivermectin inhibits DNA polymerase UL42 of pseudorabies virus entrance into the nucleus and proliferation of the virus in vitro and vivo. Antiviral Research 159, 55-62.

Mahmud, R. (2020). A Randomized, Double-Blind Placebo Controlled Clinical Trial of Ivermectin plus Doxycycline for the Treatment of Confirmed Covid-19 Infection.

Marik, P.E., Kory, P., Varon, J., Iglesias, J., and Meduri, G.U. (2020). MATH+ protocol for the treatment of SARS-CoV-2 infection: the scientific rationale. Expert Review of Anti-infective Therapy, 1-7.

Mastrangelo, E., Pezzullo, M., De Burghgraeve, T., Kaptein, S., Pastorino, B., Dallmeier, K., De Lamballerie, X., Neyts, J., Hanson, A.M., Frick, D.N., Bolognesi, M., and Milani, M. (2012). Ivermectin is a potent inhibitor of flavivirus replication specifically targeting NS3 helicase activity: new prospects for an old drug. Journal of Antimicrobial Chemotherapy 67, 18841894.

Maurya, D.K. (2020). A combination of ivermectin and doxycycline possibly blocks the viral entry and modulate the innate immune response in COVID-19 patients.

Morgenstern, J., Redondo, J.N., De Leon, A., Canela, J.M., Torres, N., Tavares, J., Minaya, M., Lopez, O., Placido, A.M., and Castillo, A. (2020). The use of compassionate Ivermectin in the management of symptomatic outpatients and hospitalized patients with clinical diagnosis of COVID-19 at the Medical Center Bournigal and the Medical Center Punta Cana, Rescue Group, Dominican Republic, from may 1 to august 10, 2020. medRxiv.

Nadkarni, G.N., Lala, A., Bagiella, E., Chang, H.L., Moreno, P.R., Pujadas, E., Arvind, V., Bose, S., Charney, A.W., Chen, M.D., Cordon-Cardo, C., Dunn, A.S., Farkouh, M.E., Glicksberg, B.S., Kia, A., Kohli-Seth, R., Levin, M.A., Timsina, P., Zhao, S., Fayad, Z.A., and Fuster, V. (2020). Anticoagulation, Bleeding, Mortality, and Pathology in Hospitalized Patients With COVID-19. J Am Coll Cardiol 76, 1815-1826.

Nallusamy, S., Mannu, J., Ravikumar, C., Angamuthu, K., Nathan, B., Nachimuthu, K., Ramasamy, G., Muthurajan, R., Subbarayalu, M., and Neelakandan, K. (2020). Shortlisting Phytochemicals Exhibiting Inhibitory Activity against Major Proteins of SARS-CoV-2 through Virtual Screening.

Niaee, M.S., Gheibi, N., Namdar, P., Allami, A., Zolghadr, L., Javadi, A., Karampour, A., Varnaseri, M., Bizhani, B., and Cheraghi, F. (2020). Ivermectin as an adjunct treatment for hospitalized adult COVID-19 patients: A randomized multi-center clinical trial. 


\section{Efficacy of Ivermectin in COVID-19}

Perera, R.A., Tso, E., Tsang, O.T., Tsang, D.N., Fung, K., Leung, Y.W., Chin, A.W., Chu, D.K., Cheung, S.M., and Poon, L.L. (2020). SARS-CoV-2 virus culture from the upper respiratory tract: Correlation with viral load, subgenomic viral RNA and duration of illness. MedRXiv.

Podder, C.S., Chowdhury, N., Sina, M.I., and Haque, W. (2020). Outcome of ivermectin treated mild to moderate COVID-19 cases: a single-centre, open-label, randomised controlled study. IMC J. Med. Sci 14.

Polak, S.B., Van Gool, I.C., Cohen, D., Von Der Thusen, J.H., and Van Paassen, J. (2020). A systematic review of pathological findings in COVID-19: a pathophysiological timeline and possible mechanisms of disease progression. Mod Pathol 33, 2128-2138.

Portmann-Baracco, A., Bryce-Alberti, M., and Accinelli, R.A. (2020). Antiviral and AntiInflammatory Properties of Ivermectin and Its Potential Use in Covid-19. Arch Bronconeumol.

Rajter, J.C., Sherman, M.S., Fatteh, N., Vogel, F., Sacks, J., and Rajter, J.J. (2020). Use of Ivermectin is Associated with Lower Mortality in Hospitalized Patients with COVID-19 (ICON study). Chest.

Ravikirti, Roy, R., Pattadar, C., Raj, R., Agarwal, N., Biswas, B., Majhi, P.K., Rai, D.K., Shyama, Kumar, A., and Sarfaraz, A. (2021). Ivermectin as a potential treatment for mild to moderate COVID-19 - A double blind randomized placebo-controlled trial. medRxiv, 2021.2001.2005.21249310.

Robin, R.C., Alam, R.F., Saber, S., Bhiuyan, E., Murshed, R., and Alam, M.T. (2020). A Case Series of 100 COVID-19 Positive Patients Treated with Combination of Ivermectin and Doxycycline. Journal of Bangladesh College of Physicians and Surgeons, 10-15.

Rodriguez-Nava, G., Trelles-Garcia, D.P., Yanez-Bello, M.A., Chung, C.W., Trelles-Garcia, V.P., and Friedman, H.J. (2020). Atorvastatin associated with decreased hazard for death in COVID-19 patients admitted to an ICU: a retrospective cohort study. Crit Care 24, 429.

Rubin, R. (2020). As Their Numbers Grow, COVID-19 “Long Haulers" Stump Experts. JAMA 324, 1381-1383.

Salvarani, C., Dolci, G., Massari, M., Merlo, D.F., Cavuto, S., Savoldi, L., Bruzzi, P., Boni, F., Braglia, L., Turra, C., Ballerini, P.F., Sciascia, R., Zammarchi, L., Para, O., Scotton, P.G., Inojosa, W.O., Ravagnani, V., Salerno, N.D., Sainaghi, P.P., Brignone, A., Codeluppi, M., Teopompi, E., Milesi, M., Bertomoro, P., Claudio, N., Salio, M., Falcone, M., Cenderello, G., Donghi, L., Del Bono, V., Colombelli, P.L., Angheben, A., Passaro, A., Secondo, G., Pascale, R., Piazza, I., Facciolongo, N., Costantini, M., and Group, R.-T.-C.-S. (2020). Effect of Tocilizumab vs Standard Care on Clinical Worsening in Patients Hospitalized With COVID19 Pneumonia: A Randomized Clinical Trial. JAMA Intern Med.

Scheim, D. (2020). "From Cold to Killer: How SARS-CoV-2 Evolved without Hemagglutinin Esterase to Agglutinate, Then Clot Blood Cells in Pulmonary and Systemic Microvasculature". SSRN).

Schmith, V.D., Zhou, J., and Lohmer, L.R. (2020). The Approved Dose of Ivermectin Alone is not the Ideal Dose for the Treatment of COVID-19. Clinical Pharmacology \& Therapeutics.

Sen Gupta, P.S., Biswal, S., Panda, S.K., Ray, A.K., and Rana, M.K. (2020). Binding mechanism and structural insights into the identified protein target of COVID-19 and importin-alpha with invitro effective drug ivermectin. J Biomol Struct Dyn, 1-10.

Shouman, W. (2020). Use of Ivermectin as a Prophylactic Option in Asymptomatic Family Close Contact for Patient with COVID-19. Clincal Trials.gov.

Siegelman, J.N. (2020). Reflections of a COVID-19 Long Hauler. JAMA.

Soto-Becerra, P., Culquichicón, C., Hurtado-Roca, Y., and Araujo-Castillo, R.V. (2020). Real-world effectiveness of hydroxychloroquine, azithromycin, and ivermectin among hospitalized COVID-19 patients: results of a target trial emulation using observational data from a 


\section{Efficacy of Ivermectin in COVID-19}

nationwide healthcare system in Peru. Azithromycin, and Ivermectin Among Hospitalized COVID-19 Patients: Results of a Target Trial Emulation Using Observational Data from a Nationwide Healthcare System in Peru.

Sparsa, A., Bonnetblanc, J., Peyrot, I., Loustaud-Ratti, V., Vidal, E., and Bedane, C. (Year). "Systemic adverse reactions with ivermectin treatment of scabies", in: Annales de Dermatologie et de Venereologie), 784-787.

Spoorthi V, S.S. (2020). Utility of Ivermectin and Doxycycline combination for the treatment of SARS-CoV2. International Archives of Integrated Medicine 7, 177-182.

Suravajhala, R., Parashar, A., Malik, B., Nagaraj, A.V., Padmanaban, G., Kishor, P.K., Polavarapu, R., and Suravajhala, P. (2020). Comparative Docking Studies on Curcumin with COVID-19 Proteins.

Swargiary, A. (2020). Ivermectin as a promising RNA-dependent RNA polymerase inhibitor and a therapeutic drug against SARS-CoV2: Evidence from in silico studies.

Tambo, E., Khater, E.I., Chen, J.H., Bergquist, R., and Zhou, X.N. Nobel prize for the artemisinin and ivermectin discoveries: a great boost towards elimination of the global infectious diseases of poverty.

Tay, M.Y.F., Fraser, J.E., Chan, W.K.K., Moreland, N.J., Rathore, A.P., Wang, C., Vasudevan, S.G., and Jans, D.A. (2013). Nuclear localization of dengue virus (DENV) 1-4 non-structural protein 5; protection against all 4 DENV serotypes by the inhibitor Ivermectin. Antiviral Research 99, 301-306.

Varghese, F.S., Kaukinen, P., Gläsker, S., Bespalov, M., Hanski, L., Wennerberg, K., Kümmerer, B.M., and Ahola, T. (2016). Discovery of berberine, abamectin and ivermectin as antivirals against chikungunya and other alphaviruses. Antiviral Research 126, 117-124.

Veit, O., Beck, B., Steuerwald, M., and Hatz, C. (2006). First case of ivermectin-induced severe hepatitis. Transactions of the Royal Society of Tropical Medicine and Hygiene 100, 795-797.

Wagstaff, Kylie m., Sivakumaran, H., Heaton, Steven m., Harrich, D., and Jans, David a. (2012). Ivermectin is a specific inhibitor of importin $\alpha / \beta$-mediated nuclear import able to inhibit replication of HIV-1 and dengue virus. Biochemical Journal 443, 851-856.

Yang, S.N.Y., Atkinson, S.C., Wang, C., Lee, A., Bogoyevitch, M.A., Borg, N.A., and Jans, D.A. (2020). The broad spectrum antiviral ivermectin targets the host nuclear transport importin $\alpha / \beta 1$ heterodimer. Antiviral Research 177, 104760.

Young, B.E., Ong, S.W., Ng, L.F., Anderson, D.E., Chia, W.N., Chia, P.Y., Ang, L.W., Mak, T.-M., Kalimuddin, S., and Chai, L.Y.A. (2020). Viral dynamics and immune correlates of COVID19 disease severity. Clinical infectious diseases: an official publication of the Infectious Diseases Society of America.

Zhang, J., Rao, X., Li, Y., Zhu, Y., Liu, F., Guo, G., Luo, G., Meng, Z., De Backer, D., and Xiang, H. (2020a). High-dose vitamin $C$ infusion for the treatment of critically ill COVID-19.

Zhang, X., Song, Y., Ci, X., An, N., Ju, Y., Li, H., Wang, X., Han, C., Cui, J., and Deng, X. (2008). Ivermectin inhibits LPS-induced production of inflammatory cytokines and improves LPSinduced survival in mice. Inflamm Res 57, 524-529.

Zhang, X., Song, Y., Xiong, H., Ci, X., Li, H., Yu, L., Zhang, L., and Deng, X. (2009). Inhibitory effects of ivermectin on nitric oxide and prostaglandin E2 production in LPS-stimulated RAW 264.7 macrophages. Int Immunopharmacol 9, 354-359.

Zhang, X.-J., Qin, J.-J., Cheng, X., Shen, L., Zhao, Y.-C., Yuan, Y., Lei, F., Chen, M.-M., Yang, H., and Bai, L. (2020b). In-hospital use of statins is associated with a reduced risk of mortality among individuals with COVID-19. Cell metabolism 32, 176-187. e174. 